\title{
Három község a Zselic nyugati szélén 1921-27 között Kadarkút, Bárdudvarnok, Hedrehely népének életkörülményei
}

\author{
KNÉZY JUDIT \\ H-1149 Budapest, Pillangó park 16/b. fsz. 2., \\ e-mail: jknezy@freemail.hu
}

\begin{abstract}
KnEZY, J.: Three villages between 1921 and 27 on the Western edge of the Zselic region.

Abstract: This study is based on a nationwide questionnaire of National Faluszövetség (Assotiation of Villages) on the region general conditions conducted in 1921 and 1925, and it compares the public administration, legal, intellectual and communal state of three settlements in the North-Western region of Zselic in Somogy County: Kadarkút, Bárdudvarnok, Hedrehely. It also gives the readers a picture of the region level of farming techniques and the relation to other settlements of the three villages, the local conditions of faires and pastures, main agricultural methods. It also examines the farming land and living ground distributions and prices of houses and field. The source is saved in Archiv of the original scrifts in the Hungarian Agricultural Museum as heritage of $\mathrm{Dr}$ Antal Bodor.
\end{abstract}

Keywords: local situation in public administration, intellectual life and communal services, the level of regional farming techniques, rural lifestyle

A Zselic tájegységgel, táji, történeti, gazdasági falucsoportjaival ${ }^{1}$, egyes községek történetével, regionális, történeti, gazdasági, társadalmi kapcsolatrendszereikkel, sajátos hagyományaikkal és ezek változásaival sokféle tanulmány, adatközlés foglalkozott. Mégis számos fehér folt vár még a kutatókra, sok község múltjáról, arculatáról keveset tudunk. 2017 márciusára több tudományág tanulságait alapul vevő, azt értékelő csoport tagjai készítettek egy kötetet, melyben a szervezők jövőkutatási céllal foglalták össze az addig írásban megjelent eredményeket, kiegészítették a közelmúlt adataival és részben a továbblépés lehetőségeivel is. ${ }^{2}$ Ebben a munkában magam is részt vettem egy néprajzi összefoglalóval, ${ }^{3}$ melynek összeállítása során számos új kérdés is felmerült bennem. Ezért gondoltam a még nem feldolgozott dokumentumok feltárására. Egy 1921-27 között készült forrásanyag alapján kísérlem meg felvázolni néhány kiválasztott zselici község helyzetét, az első világháborút követő évekből. A helyi hatóságokhoz 1921-ben és 1925-ben 4-4 oldalas kérdőíveket küldtek szét az ország falvaiba Dr. Bodor Antal igazgató és Bodó János országgyűlési képviselő, ügyvezető igazgató a Falu Or-

1 Gönyey Ébner 1931. 89-110., 1933. 153-156. Kogutowitz 193036. 352. Kósa 1991. 248-265 Knézy 2001.71-110. Borsos 2011. Paládi Kovács 2011. 543-555.

2 Dr Gáspár Tamás szerkesztő, Regionális hálózatok és stratégiai fejlesztés. Zselic példája. Budapest Gazdasági Egyetem (BGE) Kiválósági kutatások pályázat. Budapest 2017. március 1. 659. Kézirat

3 Knézy Judit, A Zselic kulturális hálózata, társadalmi, gazdaság csoportjainak és néprajzának alakulása 1945-ig. Ld. 2. jegyzet Budapest 2017. 333-363. Kézirat szágos Földmüves Szövetkezet vezetőinek aláírásával. A korábbi kérdőívben található adatokra hivatkozva kérték a később kiküldött kérdőívben az 1921-1926 közötti változások jelzését is. Bodor Antal később könyvet is írt és egyetemi előadásokat is tartott részben a beérkezett anyagból, részben annak továbbfejlesztéséböl (falusi egyletekről, körökről, a falufejlesztés alapvető szempontjairól, helyismereti anyagok számbavételéről). ${ }^{4} \mathrm{Az}$ országosan elvégzett munka eredménye, beküldött példányai Bodor Antal birtokában maradtak, aki később föképp statisztikákkal egészítette ki a visszaküldött válaszokat. ${ }^{5}$ Hagyatékát a Magyar Mezőgazdasági Múzeum vette meg az özvegytől 1956-ban és 1965-ben könyveivel és Bodor Antal által később összeállított statisztikákkal. Az egész hagyaték leltározása 1969-70-ben történt meg a múzeum adattárának eredeti iratgyüjteményébe. Számítógépes nyilvántartását, feldolgozását és elemzését pedig 2016 szeptemberéig Takáts Rózsa végezte el, tanulmánya elérhető a világhálón is. ${ }^{6} \mathrm{~A}$ Néprajzi Múzeumba az anyag kisebb része került. ${ }^{7}$

4 Bodor Antal (1875-1955), jogász, ügyész, több lap szerkesztője, egyesületvezető és egyetemi tanár: a községfejlesztési, közigazgatási ügyek kutatója, írója, magyarországi helyismereti bibliográfia összegyűjtője. 1920-től az Országos Faluszövetség főtitkára, majd igazgatója stb. Ld.. Gazda 1984. Molnár 1987. 239-242. ismertetik munkásságát, írásait, melyek 1914-1944 között jelentek meg, ezekről nem írok.

5 A parasztság életének jobbításáról két nagy gondolkodó különféleképpen vélekedett a 20. század fordulóján: Darányi Ignác erős kisgazdaréteget kívánt létrehozni, s a mezőgazdaságban tevékenykedő minden csoport, réteg jogi helyzetét rendezni. Kiemelkedően jó miniszter volt alapos és körültekintő szakmai, jogi és szociálpolitikai törvényeivel és intézkedéseivel a Kárpát medence egésze viszonylatában. A földosztási tervei nem úgy valósultak meg, ahogy szerette volna. A szakoktatás kiterjesztése, kedvezményes betelepítések és munkásházépítések, munkásbérek rögzítése, munkavállaló és munkaadó jogi helyzetének szabályozása, állategészségügy országos hálózata, szőlőtelepítési programja mind elöremutató volt. Ld. Kovács 2000. 48-54. Neszmélyi 2000. 77-92, Gyáni 2000. 94-11.

Bodor Antal már a „tenyérnyi” kis hazában próbált volna a kis falvak népének segíteni többek között a közterheik könnyebbítésével, adóügyek rendezésével, betelepítésekkel, munkatempójuk gyorsítását tagosítással, utak javításával, életkörülményeik felmérésével. Kérdőívei e terveket készítették elő.

6 Takáts Rózsa, Bodor Antal hagyatéka a Magyar Mezőgazdasági Múzeumban 2016. szeptember. A teljes községnévsor és táblázat Magyar Mezőgazdasági Múzeum Adattára és Könyvtára (MMM Al 6998. http :www.ksh.hu/apps/!cp.hnt_history.show?fullid=20063 és http://mek.oszk.hu/cgi-bin/thes.cgi?desc=Dad§trunc=1§f=thes. A kérdőivekhez később statisztikai kartonokat is készített Bodor Antal 1910-20 közöttröl 1853-40 közöttröl, és 1955-ben is. Ezek leltári száma MMM AI III 6916/1.2. és MMM AI 6999. Az 1910-20 közötti kék kartonok mellett térképkivágatok is vannak, esetenként dülölisták és térképvázlatuk.

7 EA 10182 jelzet. Helyismereti Adattár 146 p. 17.old melléklet Alföld, Felvidék 1930-1954. Letéti sz. 32/1954. 


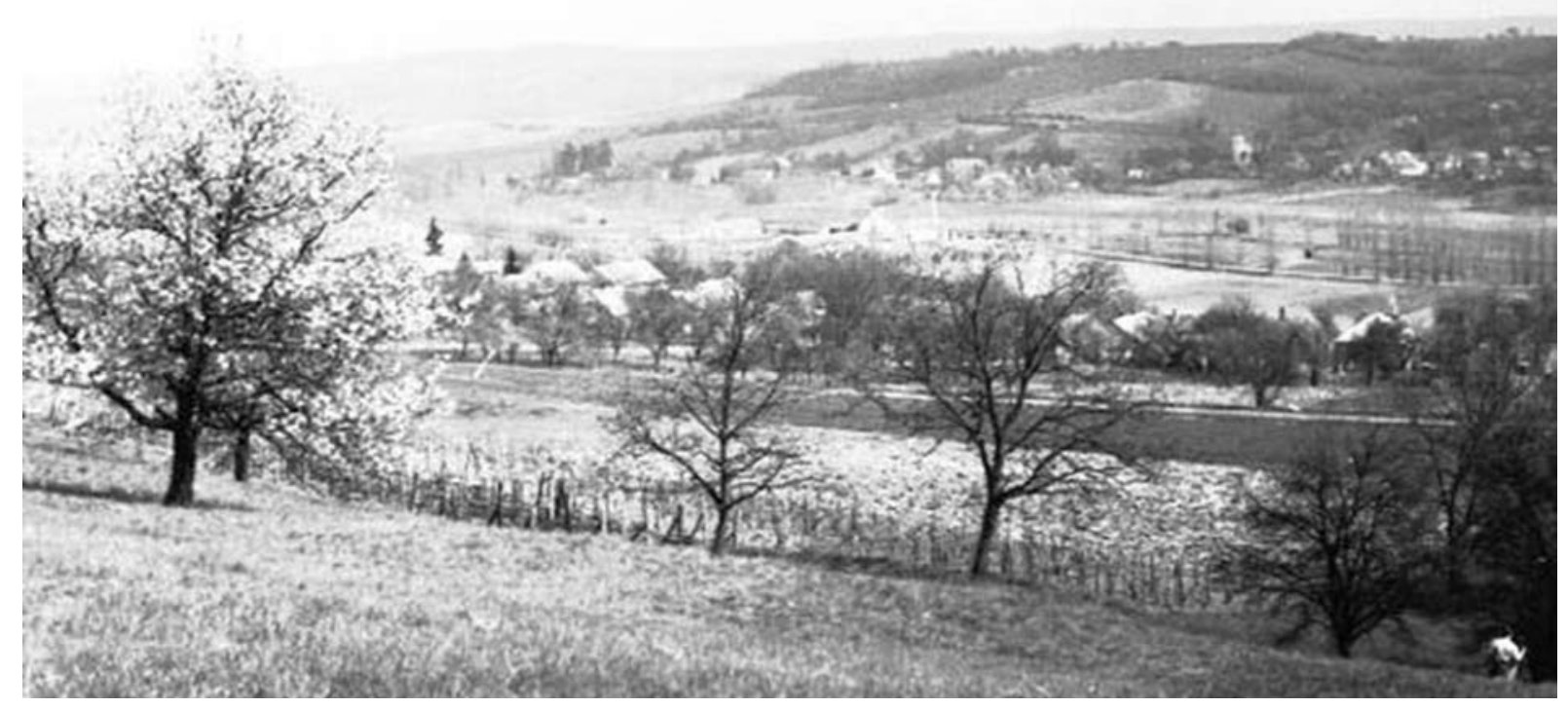

1. ábra. Zselici táj a szilvásszentmártoni szőlöhegyröl ÉK felé, a háttérben Zselickisfalud. Sási János felvétele. RRM NF-25.117

A hatalmas forrásanyagból ezúttal mindössze három község esetében veszem nagyító alá a kérdőíves válaszokat. A választás - részben a mai falusi turizmus helyi gondjai miatt is - arra késztetett, hogy a jó levegős, gyönyörü dimbes-dombos, erdős, szőlőhegyes, patakos, változatos Zselicröl adjak híradást, megcsillogtatva a sokszínű néprajzi sajátságokat is (1. ábra). Statisztika és dűlölista is fennmaradt két vizsgált községről, dűlöés községtérkép vázlattal együtt, de Bárdudvarnokról nem. Sem képeslapok, sem fényképek nem kerültek be a Mezőgazdasági Múzeumba Somogyból, rövid községtörténetek se. A kérdőívben pedig jelezték, hogy ezekre is számítanának. A kérdőíves válaszokban közölt statisztikák az 1910 körüli számbavételek alapján íródtak, a háború utáni 1919-26 évekből kevés a számszerü adat. A gyűjtés az egész Kárpát-medence magyarlakta községeire kiterjedt, még az elszakított országrészekre is. Bodor Antal korábban egyes falvak településtörténeti kérdéseivel foglalkozott. Felismerte, hogy az aprófalvak lakosságát aránytalanul jobban sújtják a közterhek, mint a népesebbeket, s ez szellemi és anyagi gyarapodásukat lassítja, vagy vissza is fordítja, ezekről is érdeklődött. E gondon többek között hozzátelepítésekkel, illetve központok létrehozásával, hathatós szociális intézkedésekkel, a falut segítő részben önerős, de államilag támogatott szervezetekkel kívánt volna segíteni. A kérdőív szempontjait mindezek előre bocsátása talán világosabbá teszi. Mint jogász, statisztikus, közigazgatási szakember és az agrárállapotok felmérője súlypontoz bizonyos kérdéseket, összefüggö vonásokat. $A$ helyi hagyományok egy részét (szokások, táncok, viselet, sajátos háziipar) is firtatja komolyabb rendszer nélkül, vázlatosan. Ezért utóbbi kérdései alig hoztak eredményeket. Mint néprajzos, elsősorban a kérdőívben kért helyi képeslapok illetve fényképek teljes elmaradását sajnálom. Egy jó fotó sokszor többet elárul, mint egy leírás. Képeslapok készültek a nagyobb helységekről, a Balaton mellékéröl (az ország más tájairól, híres borvidékekről, fürdőkröl, búcsújáróhelyekről, nagyobb piacok, vásárok jeleneteiről való rajzok mellett fotókban is) a 19. század második felében. Somogyban fényképeket már a 19. század utolsó évtizedeiben készíttettek nagy- és középbirtokosok is a birtokukról, kastélyukról, majorjaik épületeiről, állatállományukról, helyenként a községről is, sőt az alkalmazottakról is. A parasztcsaládok közül a módosabbak kisebb mértékben már a 19. század végén megörökíttették magukat. A mátkapárt többnyire müteremben fotózták. Fennmaradtak csoportképek is: rajta családok, lakodalmi vendégek, nagyobb gazdáknál aratók, cséplők, fogatok, díjnyertes állatok, gondozóik is. A falusi nép köréből az Amerikába kivándorlók is hagytak itthon magukról képet illetve vittek magukkal fotót az itthoniakról. Még inkább fontosnak tartották az első világháború idején, hogy a bevonulók és családtagjaik képet őrizhessenek egymásról (2. és 3. ábra). A kis méretű, esetleg díszes paszpartójú és bekeretezett katonaképek a szoba falán a fiókos sublót felett emlékeztettek szeretett fiúkra, apjukra. Az esküvői páros kép olykor színezett, és felismerhetetlenségig stilizáltra sikerült, ez általában a házaspár ágya felett díszlett. Ez a néhány fénykép nagyon becses volt, aligha adták volna át a válaszadó jegyzőnek. Az utcaképek (fotók, levlapok) ma is nagyon sokat segítenének a müemlékeseknek a településképek rekonstrukciójának tervezésében. A kaposvári Rippl-Rónai Múzeumban a 20. század elejéről inkább parasztokat megörökítő képek vannak elég jelentős számban a néprajzi fotótárban főképp kaposvári, barcsi és csurgói hivatásos fényképészeknek, de amatőröknek köszönhetően is. Már az 1920-30-as években Gönczi Ferenc, Gönyey Ébner 


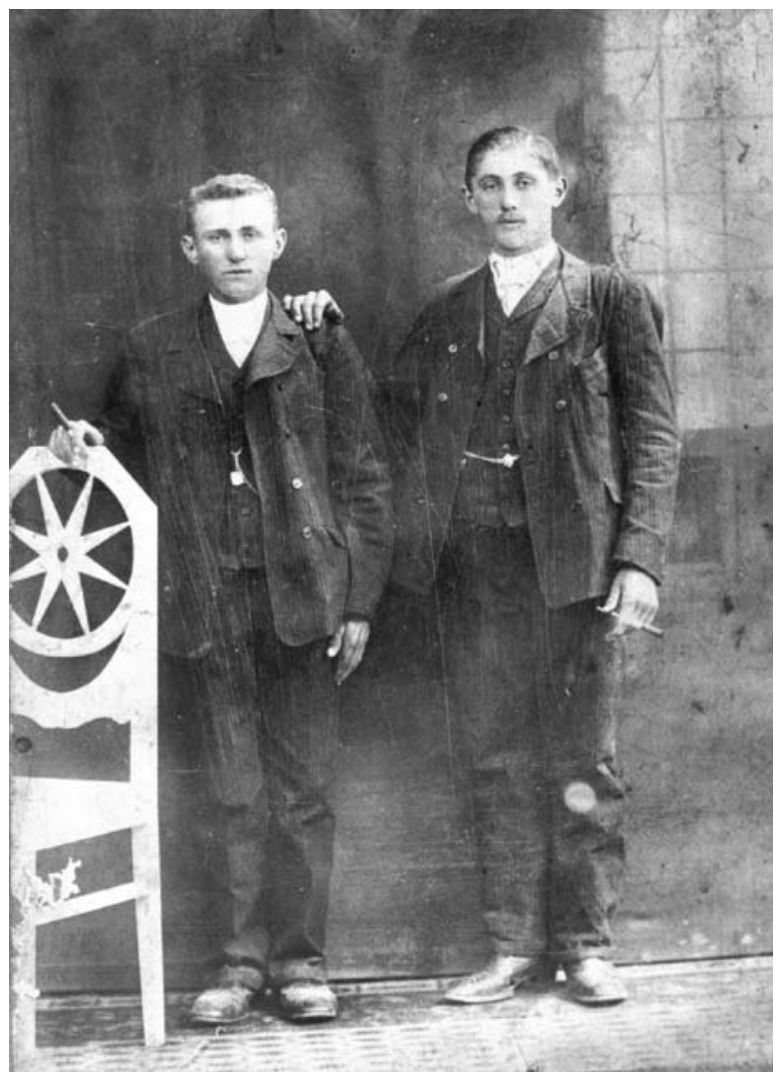

2. ábra. A gálosfai jómódú Rippl család fiai az első világháború idején. Szerzője ismeretlen. Repró: Gőzsy Gáborné. RRM NF-8545

Sándor felfigyelt mind a hivatásos fényképészek, mind az amatőrök anyagára, amelyekből már ők is szereztek darabokat a múzeumoknak. Ezzel párhuzamosan néprajzkutatók, földrajzosok, helytörténetírók is ráálltak a fényképezésre sokféle témában, könyveikben ezeket közzé is tették. Vármegyei monográfiák, népmüvészeti kötetek színes és fekete-fehér fényképsorozatokkal és rajzokkal együtt jelentek meg. ${ }^{8}$

Tanulmányom a kérdőívekre adott válaszokra koncentrál. Ugyanazokat a kérdéseket tették fel minden helységben. A válaszadók nem mindig töltötték ki alaposan a rovatokat, üresen is hagyták, vagy kihúzták, nemleges választ adtak olykor is, ha nem lett volna indokolt. Sokszor a legjellemzőbb kérdéseket nem válaszolták meg (pl. milyen és hány mezőgazdasági gép volt a községben, milyen növényfajtákat, állatfajtákat részesítettek előnyben, hiszen ez az idő éppen a fajtaváltások kezdete volt). Hiányos adatokat kapunk arról, hogy milyen építőanyagot használtak, még kevesebbet

8 Endrei 1912. 197-222. Tájakról, épületekről főképp kastélyokról, templomokról, gyárakról, híres személyekröl vannak benne képek, de néhány már akkor ismert somogyi népviseletről is. Malonyay 1911. 2-304. III.k. A pásztorélet tárgyaiból zselicieket is közöl id Kapoli Antal kadarkúti, illetve Kopaszpusztai juhász faragó munkáit 126, 127. 129.p, Malonyay 1912. IV. kötetben aránylag kevés a zselici fotó pl. lipótfai ház, szennai viseletek, zselici templombelsők, szennai temetörészletek, hímzések: 109 192-4, 209. 233, 239. 263-264.

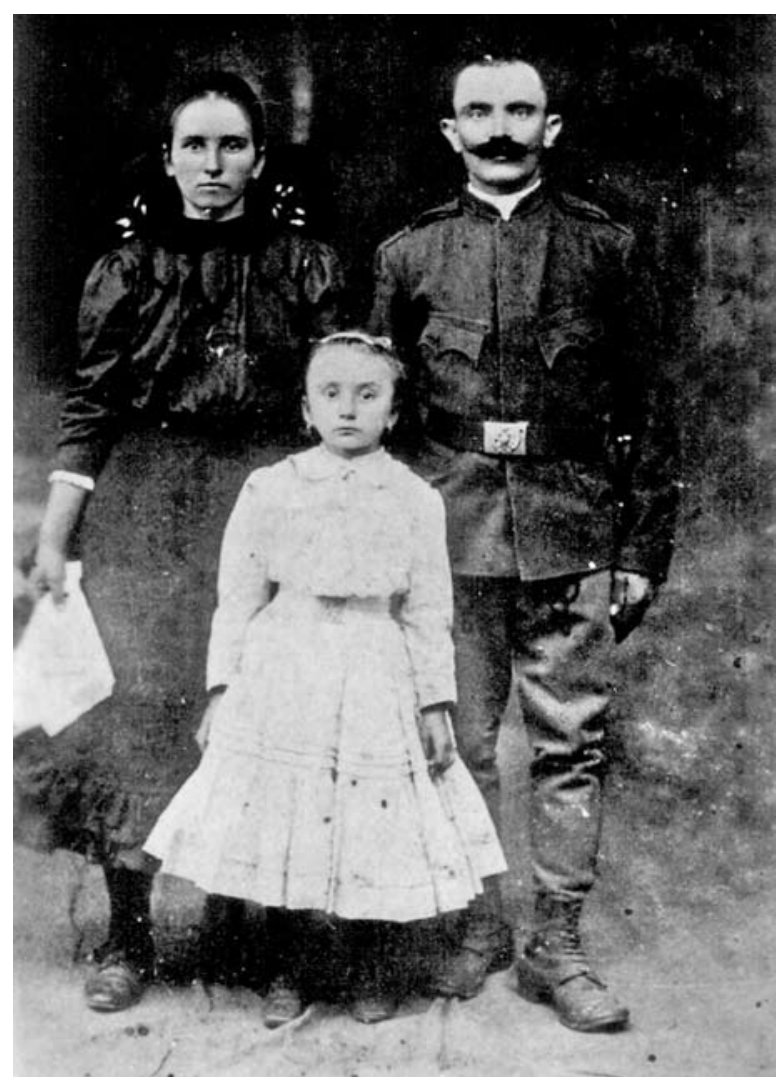

3. ábra. Kaposszentbenedek (ma Bárdudvarnok) református gazdacsalád az első világháború idején. Kozári Kovács József ajándéka, szerzője ismeretlen.

Repró Király Béla. A menyecske Kaposújlakról ment oda férjhez. RRM NF-5128

tudunk meg a háziiparról és a keresettebb iparosokról. A legtöbb kérdést azonban megválaszolták, így lényegében homogén forrással van dolgunk.

Ez az időszak nemzetünk életének súlyos mélypontja, a bukott háború, az ország feldarabolása, családok és birtokaik kettészakítása, háborús károk, fontos erőforrások, piacok, vásárok, beszerzési lehetőségek elvesztése, új piacok keresése, tartalékolt készletek, munkaeszközök és más javak hiányosságai, az általános elszegényedés miatt. A falvak népének „színevirága" megfogyatkozott, az aktív munkaképes férfiak száma csökkent, számos család magára maradt. De kiderül a válaszokból, hogy méltóképp meggyászolhatták, számbavették a „hősi halottakat”, emléktáblákat készíttettek elhunyt szeretteik nevével. Ebben az időszakban sajnos ez az emberveszteség-lista a legprecízebb. Több helyen az elrekvirált harangok helyébe vásároltak újat, másutt szobrot, emlékmúvet emeltek. Mindezt az állam is támogatta, megemlékezéseket is tarttatott, s a korabeli sajtó is beszámolt a nemzet gyászáról.

A falvak népe megfeszített erővel igyekezett folytatni életét. Kiderül közvetve a válaszokból, hogy a 20. század elején megindult kezdeményezések (gépek beszerzése, szövetkezetek, egyesületek alakítása, gazdasági ismeretterjesztő előadások, tanfolyamok rendezése, ismétlőiskolások képzése gazdasági témákban 
is) nem mindenhol folytatódtak, abbamaradtak, vagy el se kezdődtek. Az élet nagyjából a meglévő hagyományok alapján folytatódott, bár a háborút megjárt és ott sok mindent tapasztalt hazaérkezőkben többé-kevésbé élt a vágy, hogy valamit változtatni kellene az életükön, erre több adatközlőm visszaemlékezett, de azzal a kitétellel, hogy változtatni, " ha lenne rá lehetőség."

\section{A kiválasztott falvak helyzete, mozgástere és a kér- dőív szempontjai}

A felhasznált forrás nem néprajzi, hanem jogi, pénzügyi, statisztikai, agrártörténeti jellegű, mely eredetileg széleskörü statisztikai összehasonlítások révén nyerte volna el valós eredményét. Bodor Antal készített erre vonatkozóan statisztikai táblázatokat. Tanulmányom a gazdasági válság kitörése és a háború befejezése közötti "légüres tér" nehéz idő állapotait faggatja elsősorban a kérdőíves válaszok alapján saját és mások néprajzi észrevételei segítségével. Helyenként megkísérlem felvillantani az itt élt paraszti közösség sajátos arculatát, életmódját, esetenként mentalitását. A kérdőívek is rákérdeznek a falu népének véleményére is. Itt a Zselic északnyugati, nyugati részén fekvő helységek népe a megyén belül általánosságban a leginkább hagyománykövetők közé sorolódott gazdálkodásában, életmódjában, szellemi kultúrájában is. ${ }^{9}$ A török idők alatt és után is folyamatosan itt élő családjaik többsége református, főképp a jobbmódúak. A 20. században e három községben katolikusok is laktak jelentős számban, más vallásúak alig, zsidók nagyobb csoportja Kadarkúton, ott Zsidó utca is volt, de Hedrehelyen is többen telepedtek le. A paraszti sorúak mellett katolikus uradalmi cselédek is gazdagították a népesség arculatát, velük alig foglalkozik a kérdőív. ${ }^{10} \mathrm{E}$ három község tárgyi néprajzi jellegzetességeiről leginkább Hedrehely és Kadarkút kapcsán születtek tanulmányok ${ }^{11}$, településváltozásaik, faépítkezésük, parasztok és pásztorok maguk készítette famunkái, és a hedrehelyi és kadarkúti fazekasok témáiból. Újabb ismeretek reményében újra értékeltem ${ }^{12}$ ezeket az adatokat. Bárdudvarnok

9 Már a 19. századi írók is leírták a dél-belső-somogyi és a zselici nép hagyományőrzését Csorba 1857. 82-89, Baksay 1896. 263370. utóbbi írt a változásokról is.(település, építkezés, paraszti vászonszövés, fehér gyász, homokon történő szőlötelepítés, táj különbségekröl is (építkezés). Jankó 1897.11-22. a faépítkezés zselici hagyományairól. Vikár 1905. a népköltészet gazdag zselici anyagából is közzétett kötetében.

10 Az uradalmi cselédeknek csak a számáról és dijazásukról szól kérdés. Eperjessy(2006. 32-36.) alapos munkája felsorolja az 1932 3-as címtár alapján az összes zselicinek és Zselic környékinek vélt községekhez tartozó pusztákat, tulajdonosaikat, bérlőit. Teljes képet ad életükröl, jogi helyzetükről, mentalitásukról, tárgyi és szellemi néprajzukról. Megrajzolja kapcsolataikat a táj paraszti közösségeivel, és lehetöleg beilleszkedésüket azok hagyományaiba.

11 Településváltozásaikról - Szenna és környékén, Kadarkúton és Hedrehelyen Hofer 1955. 125 -186, és 1972. 20-42. Cserépedény- és kályha készítőiröl Knézy 1966. 3-56,1974. 259-282. 2006. 141-154. A parasztok fafaragó tudásáról Knézy 1981. 3639. A kadarkúti szürszabókat Katona Edit említi 2001.183-186. ezek csak vásároshelyeken voltak találhatók, 1921-ben már nemigen tudtak itt megélni, de a szabók igen.

12 A három község 1921-ben a kaposvári járásban helyezkedett el. Az első rovatban a község neve, megye, járás szerepel az 1935. évi beosztás alapján. legalább annyira tartozik a Zselichez, mint a Kapos mente nyugati részéhez gazdasági, családi kapcsolataiban, anyagi és szellemi kultúrájában. Szőlőhegyein több belső-somogyi község népének volt extraneus birtoka legalább az 1920-as évek végéig. ${ }^{13}$ A Szennával határos részen a szennaiaknak voltak szőlőik, a helynevek is elárulják. E falvakkal szomszédsági, gazdasági, rokonsági kapcsolataik tovább folytatódtak a harmincas években is. A visnyei szölőhegyekben viszont Hedrehely, Kadarkút, Hencse, a belső-somogyi Lábod, Lad, Homokszentgyörgy lakosainak is volt extraneus szőlője. ${ }^{14}$ A legtöbb említett községben saját határukban is ültettek szőlőt, csak kevesebbet. A kérdőív saját falujuk határában lévő szőlők iránt érdeklődik csak, mert a filoxera vész után több ízben támogatta az állam a saját határukban való, homokos talajra telepítendő szőlők ügyét. Az értékesítési lehetőségek és a közlekedés is sajátos módon alakult ebben a területrészben. Bárdudvarnok és Kadarkút a 20-as évektől a Kaposvár-Barcs szárnyvonal előnyeit kezdte kihasználni, vasutasok is laktak e helységekben. De Hedrehely messze esett a vasúttól, legközelebb a hencsei állomás volt hozzá, szekerekkel Kadarkutat és Szigetvárt keresték fel leginkább. A Kaposvár-Gyékényesi fővonalon csak a 30-as években kapott Kaposmérő, majd 1935-ben Kaposújlak is vasútállomást. Addig a helyi és környékbeli földbirtokosok is fuvaros gazdákkal szállíttatták terményeiket, állataikat Kaposvárra ${ }^{15}$. Szennáról és környékéröl szekerekkel a töröcskei „horhón” ereszkedtek le és mentek tovább a mérői vásárra a kisgazdák. A kérdőív csak azt kérdezi, hogy a szóbanforgó községnek van-e vásártartási joga, azt nem, hogy milyen vásárokra, piacokra járnak a lakosok eladni és vásárolni, és a házaló áru-cseréről sem esik szó. Egyedül Kadarkút tarthatott vásárt már a 19. század második felétöl e három helység közül. Ennek köszönhetően is kupeckedő kereskedőivel, iparosaival, nagyszerü és jó helyen lévő vendéglőivel jobban fejlődött, mint a környező falvak. A ló- és marhacenzárok miatt a kadarkútiaktól a szomszédos falvak népe félt, ezért nemigen vallották be, hogy Kadarkúton laknak. Keresett volt, mint Kaposvár, főképp lovakat, marhát szereztek itt be a gazdák. Hasonlóan népszerüek voltak Lad, Nagybajom (sertéskínálat), Mérő, Sárd, (marha és ló, lenfonal és házivászon, iparosok termékei), Nagyatád (gabona, burgonya, hal, számosállat, dohánybegyűjtő, stb.)

13 Csököly, Gige, Kis(Rinya)kovácsi népének volt itt Bárdudvarnok határában extraneus, irtásos eredetü szölője, a csökölyiek „Szendi-, Csermányi-, Olaj-, Zsippói högyöt, Förtőst” emlegették. Nagy szőlömunkák idején kint is laktak. Knézy 1977.18-19.

14 Bodor a külterületi tartozéktelepülések szempontjából a Nagy Alföld példájából indul ki, és rákérdez mindenütt, hogy vannak-e tanyák. A Dunántúlon, Somogyban nem jellemző. Esetenként laktak kint télen át a szőlöben öregek, csőszök, koldusok a hatóság ellenzése ellenére. Viszont az állandó kijárás amúgy is szükséges volt, mivel a szölöhegyi gazdálkodás pótolta a kevés földet, rétek, kaszálók, gyümölcsfasorok, veteményes ágyások is voltak kint. A kint alvás csak a távoli birtokosokra volt jellemző. Viszont Szigetvár vásárai, piacai közelében pontosan nem tudni mikortól, de elég későn egyre többen a szölöhegyekbe költöztek ki földnélküli, „közvetítő” kereskedelemmel foglalkozók családostól, iskola is épült, mely 2000-ben még megvolt.

15 Szili 1987. 187- 219. Knézy 2012. 331-348. 


\section{HÁROM KÖZSÉG A ZSELIC NYUGATI SZÉLÉN 1921-27 KÖZÖTT KADARKÚT, BÁRDUDVARNOK, HEDREHELY NÉPÉNEK ÉLETKÖRÜLMÉNYEI}

sokadalmai ${ }^{16}$. Ide tartoznának a búcsús sokadalmak, melyek szinte piaccá nőtték ki magukat. A kérdőív iparosok, és háziipar iránt is érdeklődik, a híres, nagyobb körzetben árusítókra gondolva. Erre hiányosak a válaszok, Hedrehely fazekasait megemlítik, akik nagy körzetet láttak el Dél-Somogyban. De Kadarkúton is müködött, bár kevesebb agyagiparos. Kadarkúton és Hedrehelyen - bár azt jelzi a jegyző, hogy csak saját használatra - de szőttek vásznakat, mintásat is a parasztasszonyok. Ez jellemző volt általában az északnyugati zselici és dél-belső-somogyi református falvak törzsökös családaira. Egyik fontos szövési központjuk volt Szenna, ahonnan a vállalkozó asszonyok házaltak is saját szőtteseikkel és mintákat is rajzoltak megrendelésre. A dennai erdőből pedig talán egész Dél-Somogy szövőasszonyait ellátták a zselickisfaludi cigányaszszonyok vetélő völggyel. A Zselicben nem termett meg jó len, azt leginkább a csökölyi asszonyoktól vásárolták meg. A szennai református templomnak 1901-ben datálva és névvel ellátva ajándékozott egy pamutvászon "föszödéses" technikával díszített úrvacsora asztali terítőt Lombár Juliska (4. ábra), meggypiros „szélrózsás” széles díszcsíkkal, jól mutatva e munkában való jártasságát az itteni asszonyoknak. Takácstól csak különlegesen cifra vagy erős vásznat vásároltak.

A paraszti szövésben, az ünnepi darabokban leginkább éppen az 1920-as években kezdték a szokásos meggyszín, vörös, bordó, kék-piros, kék, fekete, fehéren fehér színű csík- majd folthatású mintákat egyes községekben még színesebbre cserélni, talán a színes gyári textilek hatására. A szigetvári vásár közelségében gabona- és fakereskedők is szerveződtek Hedrehelyen, ahonnan a gabonafelhozatal mellett, épületnek való fa, tüzifa, szerszámfa és fából készült egyéb tárgyak is bőséggel eljutottak oda. Még a vásári helypénzjegyzékek is mutatják ezt. Zselic keleti felében lévő német falvak (Bőszénfa, Almamellék) élen jártak a hidegvérü lovak beszerzésében, később jól tejelő marhák közvetítésé-

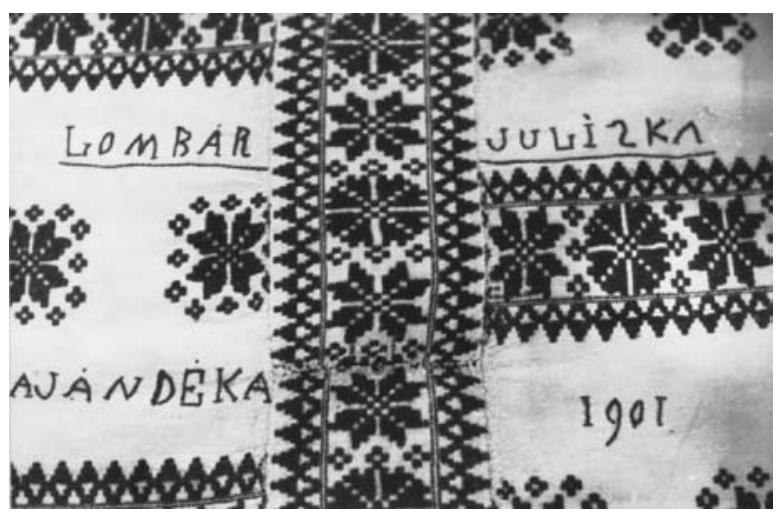

4. ábra. A szennai református templom szőttes díszü úrvacsorai asztali terítője 1901-es évszámmal és az adományozó Lombár Juliska nevével kihímezve, aki valószínüleg maga készítette. Knézy Judit felvétele. RRM NF-35.501

16 Saját gyűjtéseim a házaló árusokról, piacozásról és vásározásról Hedrehelyen, Kaposmérön, Kaposújlakon, Csökölyön, Nagykorpádon, Kutason. Knézy 1966. 54-55. 2012. 340-348. ben. Több belső-somogyi magyar község gazdáival együtt korábban lejártak a Dráván túlra is megfelelő állatokat szerezni ${ }^{17}$. Később az igényesebb marhatartásnak megfelelöbb fajtákért is messzire eljutottak Somogy területéről ${ }^{18}$. A kérdőív nem terjed ki a mívesebb fatárgyak készítésére és eladására, nem említik a háziipar kapcsán. Pedig mind a magyarok, mind a németek a legtovább foglalkoztak e területen fatárgyak készítésével eladásra is, egyfajta szakosodás is megtörtént ${ }^{19}$. Pásztorok is faragtak megyeszerte még a 20. század első felében, részben ebbe már a helyi intelligencia, uradalmi tisztek, műgyűjtők és az idegenforgalom (főképp a Balatoni Szövetség) is segített. A somogyi faragópásztorokról a legutóbbi összefogaló S. Kovács llonáé, de Eperjessy Ernő ezt még ki is egészítette azzal, hogy a Zselicben a korábban is híresek mellett még kikről nem emlékezett meg senki. Ezek a művészkedők vagy pusztákon faragtak egyéb munkáik mellett, vagy beköltöztek kis lakótelket véve községi pásztornak szegődve ${ }^{20}$. Együtt is müködtek iparosokkal kovácsokkal, bodnárokkal, asztalosokkal, bőrművesekkel. A bútorfélét többször faiparos gyártotta le és a pásztor faragta ki, mint a Kapoliak: pipatartót, kendőtartót, polcot, de széket is (5. ábra). Ügyesebb parasztember szerszámnyeleket, favillákat, kisebb-nagyobb gereblyéket, szelelölapátot, rögtörő hengert, de még talicskát, vassal kombinált faeszközöket, szerszámokat is el tudott készíteni. A Zselicben az egyik különlegesség egy szennai ember munkája, egy nem fémből, hanem fából való hatalmas, lóval húzatható fatárcsa, amit saját használatra készített (6. ábra). A háború következményei valószínúleg gátolták a fatárgyakkal való kereskedést, de az önellátást nem, sőt azt kifejezetten segítették ${ }^{21}$. A drága gyári készítésü gépek helyett eleinte és sokáig falusi iparosok és parasztbognárok remekeltek fontos földművelési eszközöket. A gazdasági ismeretszerzés fontos helyének szánták a Kadarkút melletti kétéves Szentimrepusztai Földmüvesiskolát, amely 1885 szeptemberétől müködött, kérdés, volt-e hatása a község gazdáinak müködésére. A területet Márffy Emil adta haszonbérbe és évekig bábáskodott a beindulás és megszervezés munkáiban (régi és új épületek biztosításával, munkaeszközök átadásával, addig alkalmazott cselédek

17 A kérdőív fontos pontja, hogy Amerikából jöttek-e haza korábban eltávozók. Dél-Somogyban az Amerikába vándorlást megelőzte egy kitelepedés a Dráván túlra éppen az ottani kapcsolatoknak köszönhetően és ott szereztek földet. Amerikából az általam vizsgált 15 zselici községből csak egybe érkezett haza valaki.

18 A trianoni határok meghúzása elött béreltek is legelőt a somogyi gazdák a Dráván túl, hoztak hidegvérü lovakat, sőt hozzá értő szolgagyerekeket is. (Knézy 1983-84. 381-407.) a szabásiak, csökölyiek, kutasiak stb.

19 Knézy 1981. 16-39. Már Nagyváthy (1795) is irt instrukciójában igencsak mintaszerűen arról mi minden került vásárra a zselici erdőkböl és zselici faragók kezéből. Ennek a 20. század elején is voltak nyomai. Kanyar számítása szerint a zselici falvaknak még a megyén belül is, de országosan tekintve aránylag sok erdeje volt Kanyar 1971. 117.

20 Eperjessy 2006. 565.587, S. Kovács 2001. 309-358. Kadarkút Körmendpuszta új során lakott évtizedekig Varga János juhász és faragópásztor a Kapoliak rokona. L. Imre 1975. 137-146.

21 A gazdák fiaikat elküldték gyakorlatot szerezni kőmüveshez, ácshoz, bognárhoz stb, hogy amit lehet házilag állítsanak elő a saját - megfelelő szerszámkészlettel ellátott - faragó- vagy vasas kamrájukban. 


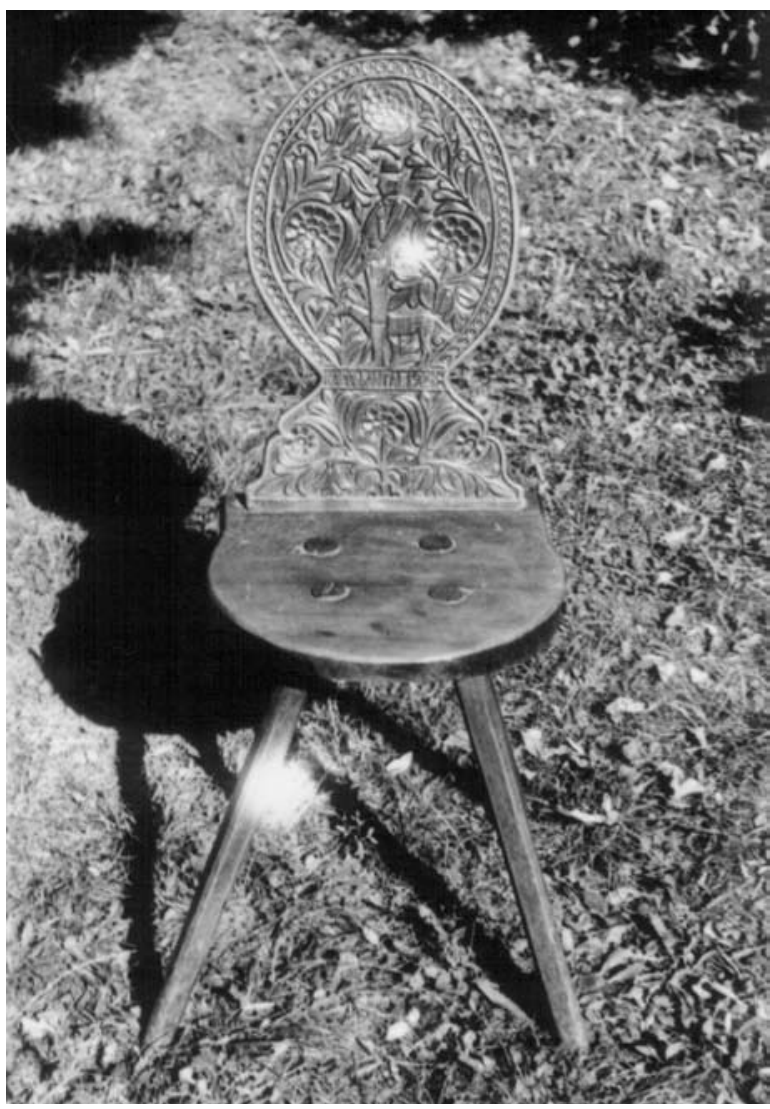

5. ábra. Id. Kapoli Antal által 1924-ben - úri megrendelésre - készített domború faragott díszü hátasszék egy sorozatból, melyben mindegyik széket más mintával díszített. Ez szék Hencsén özv. Petzmann Imréné tulajdona, majd Kadarkúton Répay Lajos kadarkúti gyógyszerészé lett. Knézy Judit felvétele. RRM NF-5366

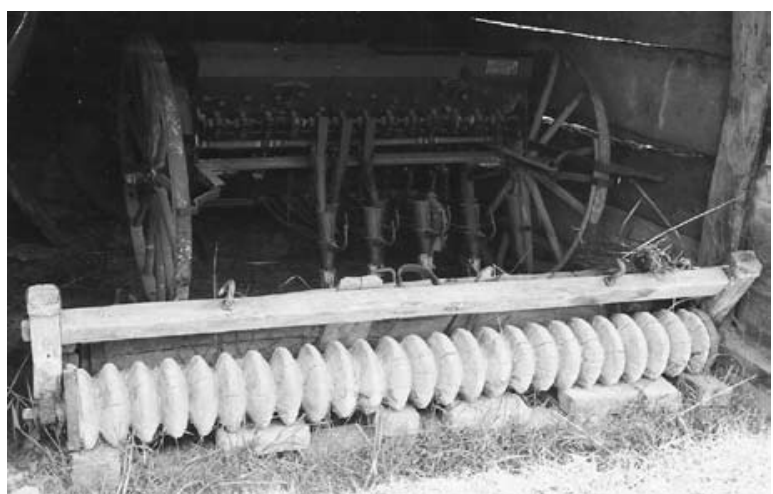

6. ábra. Szennai parasztember fából faragott tárcsája, amelyet Knézy Judit Szennán a Szennai Szabadtéri Néprajzi Gyüjteménybe gyüjtött a Hosszú családtól, később a gyüjteménybe át is telepitett pajtájukba. Knézy Judit tulajdona, Papp Tibor felvétele rendelkezésre bocsátásával, egy ideig általa adott bérezéssel, időnként pénzbeli elölegezéssel a müködéshez, mikor a minisztériumi támogatás késett). Bele is szólt a döntésekbe. Voltak bentlakásos tanulók szállással és étkeztetéssel. A bejárók e juttatásokat nem kapták, nem fizették, ők a környékröl valók voltak. A tanulás (heti 12 óra) mellett nagyon komoly gyakorlati munkát kellett végezni (télen napi 10, nyáron napi 12 órát), melyért minimálbért évi 30 forintot fizettek a tanulóknak. Az első évtizedekben az alaphangsúly a kis gazdaság szervezésén és az ehhez való tudnivalók elsajátításán volt, de 1910 utántól már az állatgyógyászat, hal- és baromfitenyésztés, méhtartás és selyemhernyótenyésztés is bekerült az általánosabb tantárgyak közé, az 1920-as években pedig a tejfeldolgozási ismereteik birtokában "sajtoda" müködtetésére is volt képesítésük. Ezenfelül az ekkor tanulók egy csoportja már gazdasági tanárrá válhatott és sokan Somogyban téli gazdasági iskolákba szerződtek el. A kisgazdaság szervezésén túl nagyobb - pl. 800 holdas - birtok szervezésének alapelveivel is megismerkedtek. A jelentkezők közül fele-fele arányban vettek fel kisgazdák fiait és cselédek vagy földnélküli emberek gyermekeit, mert utóbbiak szorgalmáról nagyon jó vélemény alakult $\mathrm{ki}^{22}$. Jelentősebb számban a községek igényesebb gazdái az 1920-as évek végétől 1945-ig küldték el fiaikat különféle gazdasági képzésekre saját községükben vagy Kaposvárra, Csurgóra.

A kiválasztott három község a Zselic északnyugati peremén van, Bárdudvarnok a Kaposmente nyugati szakaszának falvaival került a 19. század végére hasonló gazdasági helyzetbe, és alakultak kapcsolataik. Több volt a szegény kisgazda és cseléd, a katolikusok fölénybe kerültek, így kevésbé volt erős a református törzsökös családok hatása. Kivételt képezett Kaposszentbenedek a községrészek között. Hedrehely jó búzatermésével, nagyszerű számosállataival, az ún. Sziget vidéki jómódúbb községekkel is mutatott rokonságot, de elegendő erdei, jó rétjei inkább a zseliciekhez rokonították. Kadarkút vásártartási jogának megkapásával és a vasút közelségével a távolabbi vidékekkel intenzívebb kapcsolatba került, mint szomszédai. A kaposvári cukorgyárnak már 1921-ben termeltek cukorrépát, de szállítottak vonaton burgonyát, dohányt, takarmányt. Borukat a helyi kocsmárosok vásárolták fel helyben, de kereskedők is jöttek érte. Felvásárlók is akadtak helyben pl. Futura alvállalkozó, Hedrehelyen és Bárdudvarnokon Futura fővállalkozó ${ }^{23}$.

A kérdőívek a falvak szellemi és gazdasági állapotát kívánták feltárni. A táji környezettel alig foglalkoztak, jóformán csak a talajadottságokkal, mely a gazdálkodásra és a közlekedésre volt elsősorban hatással, kérdeztek a művelési rendszerekre is. A szellemi szintet (az egyletek, olvasókörök, dalárdák, népkönyvtárak, népiskolák, óvodák), a kommunális viszonyokat (vízellátottság, utak, világítás, energiaforrások), egészségügyi ellátást (orvos, bába, gyógyszertár megléte, leventemozgalom)

22 Molnár 1975. 17- 65. 1929-től már Somogyszentimrei m.kir. Mezőgazdasági Szakiskola volt a neve. Egész idő alatt voltak fizetéses hallgatók, kedvezményesek és ösztöndíjasok is.

23 Kiss 1935.II.50. 


\section{HÁROM KÖZSÉG A ZSELIC NYUGATI SZÉLÉN 1921-27 KÖZÖTT KADARKÚT, BÁRDUDVARNOK, HEDREHELY NÉPÉNEK ÉLETKÖRÜLMÉNYEI}

vizsgálták. Az iparosok száma, jelentősége nemigen derül ki, viszont az agrárhelyzet kérdései (birtokviszonyok, talajadottságok, művelési eljárások, gépek, értékesített termékek, értékesítő és begyűjtő szövetkezetek, stb.) mind-mind szerepelnek a tudakolandó dolgok között.

A történeti összefüggések közül megemlítendő, hogy e községeknek erős református identitástudata volt. Hedrehely egyháza a legelsők között alakult 1643-ban, festett kazettás református temploma 1771-ben épült, hasonló volt Kadarkúton, Kutason, Szennán. Csak a szennai maradt fenn - a mai csodálók gyönyörüségére - a hedrehelyit 1898-ban, a kadarkútit 1906-ban sajnos újjal kellett felváltani. ${ }^{24} \mathrm{~A}$ kadarkúti népi barokk istenházát a bontása előtt az egykori festőasztalosok munkáit tartalmazó templombelsővel együtt lefényképezték, s a képeket alig pár évvel később publikálták is (7. ábra).

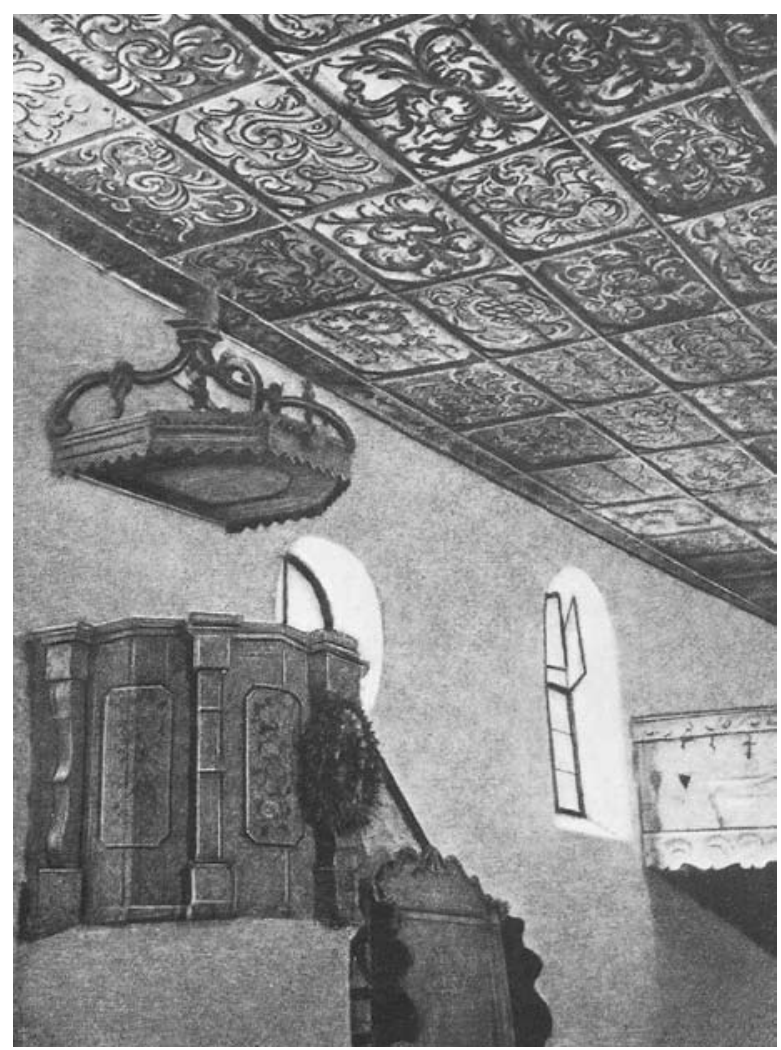

7. ábra. Az egykori fa kazettás kadarkúti református templom részlete a Malonyay által 1912-ben kiadott IV. népmüvészeti kötetböl a 207.oldaláról. Beszkennelte Kovács Gergely József

A településformákról és azok változásairól nem kérdezősködik egyik kérdőív sem. Egyetlen szó se esik a fából való építkezésről, a fáról, mint építőanyagról, amelyek alapvető vonások e területen. Viszont firtatja a kérdőív, hogy vannak-e tanyák és a keresztkérdés az, alszanak-e télen távol lévő földjeiken a kisgazdák. A válasz az, hogy nincsenek tanyák. Részben ide tartozik az a kérdés, hogy hány lakótelket osztottak ki, hány

24 A kadarkúti katolikus templom 1840-ben épült, müemlék. Csánki 1914. 74, 83. Szennáról Zentai 2011. „munkásház” épült kb. a 20. század első 20-25 évében (munkásháznak az állami kölcsönnel épült házakat nevezték $)^{25}$. De érdeklődtek az után is, hogy az 1920 utáni telekosztásoknak mi a száma és a kiosztott telkeken hány ház épült és hova. De generális községrendezés nem is került szóba. Viszont a mellékletben talált kadarkúti és hedrehelyi községtérkép, föként a belterület vázlatai felismerhetően mutatják a 19. századi mérnöki tervezésü településrendezés eredményét, a szabályosan kimért utcákat. Kadarkút 19. század végi térképét úgy tervezték és valósították meg, hogy két párhuzamos hosszú utca van, ezeket középen két templomot is tartalmazó tér köti össze, északon Körmendpuszta felé sürün beépített rövid utca fogja a két hosszú sort össze. A kérdőíves válasz alapján Körmendpusztán osztottak lakótelkeket, tehát arrafelé folytatódott az utca. A tér két oldalához közel még egy-egy kis összekötő utca is létesült korábban. Hedrehelyen három nagyjából párhuzamos utca van. Keleten a dombtetőnek nagyjából a közepén a református templom, ettöl kétoldalt hosszan sürün betelepített utcarészek folytatódnak, északon Főszög, délen Aszög (e helynevek még a régi települési rendszerből maradtak fenn). E régi utcából maradt meg az egyik leghíresebb fazekas, Turbéki István zsuppos, fatalpas, fa tornácoszlopos háza ${ }^{26}$ (8. ábra). Ettől a dombtetőtől nyugatra meredek löszdomb majd kisebb út húzódik, mintha csak egyik oldalán lennének lakóházak, másik oldalán gazdasági udvar, itt középen malmok, vásártér, téglavetők voltak. Legnyugatabbra egy másik igen hosszú utca került, mellé az első világháború után kimért proletárföldek, és az utca neve Új-Hedrehely vagy Nixbrót, azaz a szegénység utcá$\mathrm{ja}^{27}$. Somogyban és Zselicben is föként a folyamatos lakottságú helységekben a 19. század folyamán föképp a reform kortól kezdődően szükséges volt a gazdálkodás ütemének megváltoztatásához alapos területrendezés $^{28}$. A 18. század végére az egykori osztott, szálláskertes, istálló-, vagy pajtáskertes település típus, zsúfolt halmazos belső központjával, amely korábban megfelelt a félszilaj állattartásnak, már akadályozta a munkák gyors ellátását. Nem felelt meg a Mária Terézia-féle urbárium rendeleteinek. Zselicben a legtöbb hagyományőrző református község népe maga kérte a község településének újrarendezését, köztük Kadarkút és Hedrehely is. Kadarkúton 1827-ben indult meg a rende-

25 Darányi Ignác miniszter 1907. XLVI. törvénye A gazdaság munkásházak építésének állami támogatása" (Corpus juriis Hugaricae 1908. 476-482), melynek végrehajtása során a Nagy-Alföldön egész utcasorok, sőt városrészek épültek. Somogyban még kiderítendő e törvény hatása. Itt nem tudni, hogy a válaszadó jegyző milyen munkásházra gondolt.

26 Az utca másik oldalán nem sokkal a templom felé volt a nála fiatalabb Lőrinc Ferenc fazekas háza és mühelye. Padlásáról 1965ben eladatlan szép számú cserépedénykészletéből vásároltam a Rippl-Rónai Múzeumnak, és hozzá Bencsik István munkáiból, aki akkor már Szigetváron élt. Knézy 1966. 56. 1974. 259-282.

27 A helynevek gyűjtője Márton István iskolaigazgató Id. Végh 1974. 188. helység 579-81.p.

28 Panaszolták már ezt Filep 1858.226, Bosznai 1858. 15 zselici magyar községről írta le, hogy falujuk rendezetlen, istállóik külterületen vannak, házuknak nincs kéménye, földjüket nem trágyázzák, szölömüvelés a fö tevékenységük, mezei munkával nem foglalkoznak. 


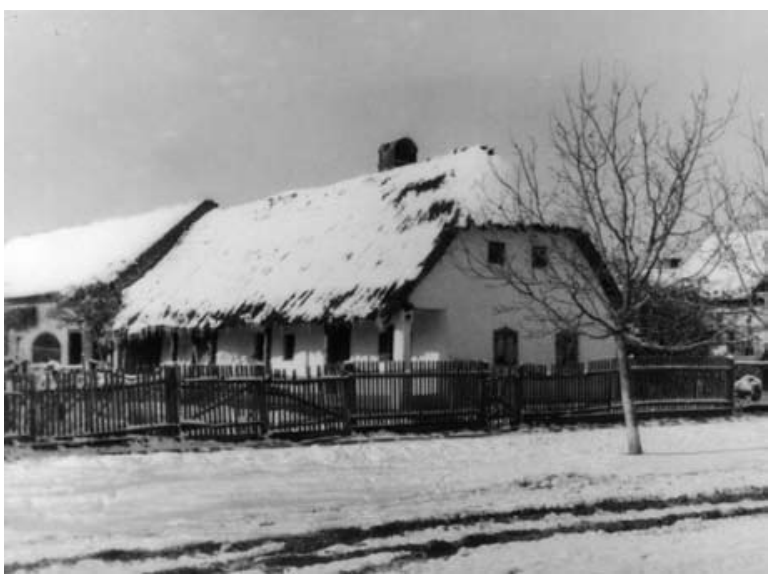

8. ábra. Turbéki István egykori fazekas lakóháza és mühelye a régi falurészből, 1965-ben Vince Lajos lakott benne. Fényképezte Knézy Judit. RRM NF-4238

zés. Pereskedések, tagosítások miatt csak 1870 után fejeződött be. Hedrehely 1836-ban kérte a községrendezést, 1843-ban kész volt a terv, amellyel egyetértettek, a kivitelezés is örömükre szolgált, mert 64 és 1/8-ad belsőségük 221 és 6/7-re nőtt ${ }^{29}$. $E$ rendezéssel helyet kaphattak újabb telepítésekhez is megfelelő helyen. A rendezés során számos épületet elbontottak, anyagát is felhasználva újat építettek, a fából valókat fagörgőkön új helyükre szállították. Kadarkút és Hedrehely térképvázlatai az 1890-es évekből már a rendezés utáni állapotot mutatják. Míg a favázas, talpas, zsuppos tetejü lakóházak pl. Szennán még az 1950-es évekig egész utcasorokat alkottak, környékén is elég szép számban maradtak addig meg, Kadarkúton Gönyey Ébner Sándor az 1920-30-as években keveset találhatott eredeti formájukban, viszont füstöskonyha berendezésekkel nagyobb szerencséje volt ${ }^{30}$. A téglagyár megléte, vályoghoz való megfelelő agyag bősége valószínüleg rontotta a favázas lakóházak esélyeit. A kérdőívekben építőanyagnak csak az agyagot, vályogot illetve téglát nevezik meg vagy semmit. Egy favázas, hosszanti tornácos zsuppos ház fényképe van a Rippl-Rónai Múzeumban talán az 1920-as évekböl Kadarkútról (9. ábra). Ennek külső képe mutatja a községrendezések idején szokásos faoszlopos tornácú, elöl félkontyolt tetejü, deszkás elülső oromzatú formát ${ }^{31}$.

29 Hofer 1955. 134-157. feltárta Kadarkút, Hedrehely, Patca, Zselickisfalud, Szilvásszentmárton településrendezésének okait, megoldását. Tarján Tamás 1981. 170-175. Vásárosbécét és Somogyviszlóét.

30 Hofer fotója 1954-ben Kadarkútról EF112003. öreg pajta András Istváné 1881-böl, az udvar végén keresztben áll, zsilipelt borona. Külön visszatért 1972. 39-40. Hedrehely átrendezésének eredményeire és az ún kettős udvarokra és ezek másutt történő előfordulásaira. Nem vette észre, hogy hasonló telepítési rendszer volt Bonnyán és Somogydöröcskén a németeknél. Ld. 1971. évi müemléki felméréseim $E A$ és $E F$.

31 Gönyey Ébner Kadarkút konyhaberendezések EF64 949-51, 65 081, füstöskonyha tüzhelye EF 65081

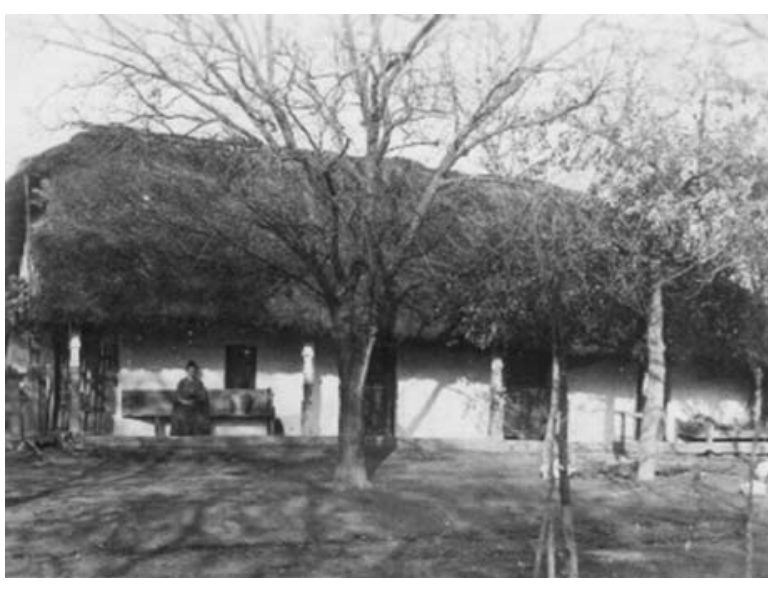

9. ábra. Kadarkúti zsuppos, favázas, fatornácos, elöl félig kontyolt és deszkaoromzatos ház. Szerzője ismeretlen. Repro Király Béla. RRM NF-6725

\section{A kérdőívben foglaltak Kadarkútról 1921-27 között}

A kérdőívekhez csatolt statisztika 1910-es adatai alapján a falu lélekszáma 2063, magyar 2054, német 4 fő, református 1063, evangélikus 14 , r.katolikus 916 , g.katolikus 1, izraelita 67. Nevezetesebb földbirtokosok: Márffy Emil, Szirt Oszkár és gróf Széchenyi Miklós.

A hősi halottak száma a kérdőív alapján 49 fő. 1932-ben 2665 fő magyar (rk. 1561, ref. 1046, ev. 2, izr. 47). Területe 6333 kh, ebböl uradalmi 3686 kh. Földbirtokos Gróf Széchenyi Ferenc. Bérlők: Birck Gyula, Rotschild Vilmos, Schwarz János ${ }^{32}$.

1921-ben írják, hogy Kadarkút a millenium idején Erzsébet királynő tiszteletére fát ültetett. Jelentős számban élnek itt értelmiségiek és iparosok is, ez kiderül abból, hogy müködik a Kadarkút és vidéke társas kör 25 fővel, polgári kör 98 fővel és a népkönyvtár. Az iparos ifjúsági kört 118 tag látogatja, de van Turul sport egylet is. A leventemozgalom részét képezi az egészséges nevelésnek, de Kadarkúton nem találják népszerünek, pedig adott számára 3800 négyszögöl testnevelö telek két futballkapuval. Waldfogel Ignác tanár foglalkozik a testneveléssel. Mindezek a társulások a nagyvendéglöben tartják összejöveteleiket. Szakmai és mükedvelö előadást is rendeztek telente 1913 óta, legutóbb 1921-ben 70-80 fönyi hallgatóságnak. Jónak tartanák a népakadémia létesítését, de ennek létrehozására terv nem született. A Faluszövetségnek nem alakult itt fiókja. A könyvtárat a földművelésügyi minisztérium ajándékozta. Rádió egy van a községben, a nagyvendéglős tervezi egynek a beszerzését, és annak lehetővé tételét, hogy sokan hallgathassák. Mozielőadás hetente egyszer történik. Könyvek vételéröl a jegyző nem tud, de arról igen, hogy korlátozott számban járatnak újságot pl. az Új Barázdát. 1921-ben állami és református népiskola is működik, utóbbi két tantermes. Ismétlőiskolások létéröl nem ír a válaszadó. A könyvtárt Pesthy Béla református tanító kezeli. Kraft József gazdaköri elnök,

32 F. Szabó 1932-33. szerkesztette címtár alapján, idézi Eperjessy Ernő 2006. 26-7. 


\section{HÁROM KÖZSÉG A ZSELIC NYUGATI SZÉLÉN 1921-27 KÖZÖTT KADARKÚT, BÁRDUDVARNOK, HEDREHELY NÉPÉNEK ÉLETKÖRÜLMÉNYEI}

gazdasági lehetőségekről tájékozódik rendszeresen, Dr. Balla Pál körorvos egészségüggyel, Mózner József plébános társadalmi kérdésekkel foglalkozik. Szerepet vállal a közös feladatokban Mosonyi Sándor, Pesthy Péter, Takáts István, Végh József, Krámi Lajos, Molnár György. Karácsony Sándor református lelkész lejegyzett meséket, mondákat (nem tudni ezek hol lehetnek azóta). Egyáltalán a község vezetői foglalkoznak a község feljlesztésével, de a nagybirtokosok, bérlők nem. Orvos, okleveles bába és gyógyszertár is szolgálja a lakosokat. $A z$ utóbbi hét évben létesült a kisvasút, hősök szobra, dalárda, tejszövetkezet, gazdakör és a körorvosi lakás (1926). Ártézi kút nincs a helységben, de közkutak létesültek. E „fúrott” kutak vízszintje 4-8 öl mélyen van. Vízművet nem terveznek. A közutakat és szekérutakat megfelelőnek találják, de nem írják, hogy le lennének kövezve. Kivétel lesz az 1924-26-ban épülö, a vasútállomáshoz vezető út. Buszjáratot Kadarkút-Kaposvár és Kadarkút-Szigetvár között szeretnének. A járdákat néhol tégla fedi. Az utcákat nem világítják semmivel ${ }^{33}$. Villanyforrásra jó lenne a két gőzmalom, nem alkalmazzák erre, vízierő pedig nincs. Van egy téglagyár. Se a két gőzmalom, se a téglagyár nem szövetkezeti alapon jött létre. Hitel- és Fogyasztási Szövetkezet működik. Terveznek szövetkezeti alapon gabonaraktár létesítését. Szerveztek tüzoltóságot két fecskendővel.

A községhez tartozó mezőgazdasági terület 6328 , a kisgazdáké 2642 hold. Terméketlen terület, futóhomok 100 hold. Idegen határban Visnyén és Hencsén van bérelt földjük. Nincsenek meg nyaraltatásra a feltételek, pl. egészséges tiszta szoba-konyhás-mellékhelyiséges lakás egész nyárra, lakáshiány miatt. A községről festmények, képeslapok, fotók nem készültek. Nem tudnak itt született híres emberről, se hozzá füződő tárgyakról.

Házhelyosztás és birtokreform hatásával elégedetlenek. Széchenyi Jenő Körmendpusztán 30 kat.holdat, Kraft János Dióspusztán 70 holdat, Németh István Sáskón 60 holdat bocsátott rendelkezésre. Ebböl 420 holdat vettek birtokba az igénylők. Nem szünt meg a földéhség, a kapott föld műveléséhez nincs megfelelő eszközük. 20 család vesztette el kenyerét. Ezek részben napszámból élnek, részben cselédnek szerződnek el vidékre. Nincs földmunkás felesleg. Amerikából az első világháború óta nem jött vissza senki. A szomszéd községek határából nem kaptak földet. A kisgazdák az uradalmi földekből 250 holdat bérelnek. Házhelyet 90-et osztottak nagyobbrészt Körmendpusztán, és a község belterületén is 1925-ben, de csak 20 ház épült. Szükség lenne nagyobb épületre közintézménynek, de nincs se a gazdáknak, se a földesuraknak felesleges épülete. Egy középszerü ház szoba-konyha-mellékhelyiséges ára 50-80 ezer korona 1921-ben. Az építkezési anyag agyag és tégla. A községi pótadó $18 \%$. Nincsenek megelégedve vele. 1925-ben a községre kirótt pótadó 4873 aranykorona. A község jövedelme ingatlanból semmi, egyebekből 25000 korona.

33 A 10. ábrán lévő ház tornácának fedeléről fakeretes üvegoldalú és nyitható ajtós mécsestartó lóg. Sötétben ilyennel világítottak, járkáltak, később istállólámpának nevezték a villany bevezetése után.
Nyomásos gazdálkodást üznek, három forgós, ennek sorrendje: őszi, tavaszi, zöld ugar. A termények fontossági sorrendje: búza, rozs, árpa v. zab, kukorica, burgonya. Nincs feketeugar csak zöld ugar (utóbbi takarmányok termesztésének forgója). A legjobb földek anyaga agyag, a legjobb minőségű szántóföldek a Keleti-dülőben vannak, leggyengébb fekete homokos földek a nyugati részen találhatók. Káros évként tartják számon 1921-et, mert szárazság volt. Trágyázást három évenként végeznek, mütrágyát nem használnak, kisgazdák alkalmaznak gépeket, cséplőt és kaszálót. De a fejlődés gátjának tartják, hogy nincs tagosítva a határ. Gyenge minőségủ a közlegelő is, mégsem kívánják javítani, nem elég nagy méretü, kevéssé fásított és kutakkal ellátott. Állatnevelésre törekednek, a tejet értékesítik a községben. Méhészettel vasutasok, tanítók, iparosok foglalkoznak, kaptáros méhészet az általános. A belsőségekben gyümölcsfákat nevelnek, nem szakosodnak egyfélére. Feldolgozzák lekvárnak, pálinkának vagy aszalják. Zöldséget csak saját használatra termelnek. 1913 óta csak 13 hold szőlőt telepítettek. A borukat a kocsmárosok vásárolják fel és értékesítik. A szőlészet fejlesztése érdekében addig terméketlen területeket szőlővel ültettek be és fásították. A kisgazdáknál holdankénti termésátlaguk: búza 8-9q, rozs $8 q$, tengeri $8-9 q$, burgonya $50 q$. Az uradalmakban a termésátlagok az elöbbieknél 2-3-4\%-kal többet jelentenek. Nincs rá adat, hogy a kisgazdák hány százaléka van eladósodva. Perről, végrehajtásról sem tud a jegyző az elmúlt hét évben. Földeladás közepes mértékü e vidéken, föként helybeli református és katolikus gazdáknak adnak el. Az uradalmi földek eladási ára azonos a kisgazdákéval. Egy-egy kisgazda földjei 6-7 helyen vannak a határban, de nem kívánnak tagosítást. Egy gazda telke, háza 1914-ben 10000 koronát ért, 1926-ban 10000000-t. A községben legjobban gazdálkodó gazdák: Hochroka Jánosné 80 holdas, Mihályi József 35 holdas, Hollósi János 18 holdas. Az aratók tizedrészt kapnak, a cséplők 20\%-ot. Egymás közti eladásnál magyar holdban számolnak, hivatalosan kataszteri holdakban. Mezőgazdasági kísérleteket a község területén a kisgazdák nem végeznek, csak a somogyszentimrei részen lévő földműves iskolában foglalkoznak ezzel a szakemberek.

Néprajzi tárgyakból, régiségekből nincs senkinek gyűjteménye. Levelezőlapok, fényképek se készülnek. A Gazdakör müködik a legjobban, a télen számtalan ismeretterjesztő előadást tartottak népes hallgatóság előtt. 8 műkedvelő előadás is volt a Strauss kocsmában legalább 200 fő előtt. Tudják, hogy Somogy megye monográfiájában vannak adatok a község múltjáról is. Krónika írással nem kíván senki se foglalkozni. Tagadják, hogy jellegzetes népművészet vagy népviselet lenne a faluban (10. ábra). 1921-ben vallják, hogy fonás-szövéssel legalább 200 család foglalkozik saját használatra, de hogy milyen saját szövésü tárgyak készülnek azt nem részletezik. $A$ jegyző, $s$ talán a kérdőív írója is „jellegzetes”- nek olyan nagyon díszes és festői, esetenként túl díszes viseletre gondolnak, amelyeket a 19. század végéröl festők, helytörténetírók és az idegenforgalom előnyben részesítettek (kalotaszegi, torockói, matyó, kalocsai, stb.), rajzoltak, fényké- 


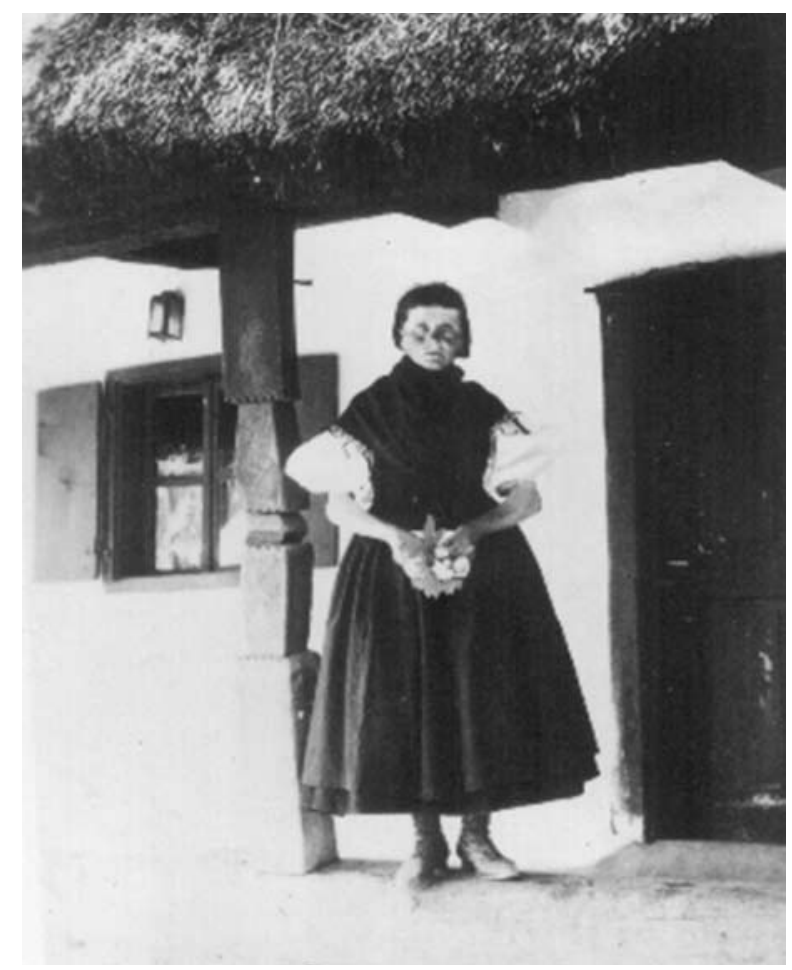

10. ábra. Kadarkúti református fiatalasszony, Balogh Katalin a 20. század elején még hagyományos ünnepi viseletben, szennaias kontyban, a Proity család házában. RRM NF-6728.

peztek. A kadarkúti paraszti viselet a maga nemében mégiscsak jellegzetes: az észak-nyugat-zselici somogyi magyar falvak ruhaegyüttesével mutatott rokonságot. Talán a hedrehelyi, szennai és környéki kissé parádésabb vagy egyszerüen tovább fennmaradt. Emlékezés anyagból tudjuk, hogy a 20. század elején a vászon felsőruházatból és színesebb - föképp kismesterek által készített (szücs, szűrszabó, kékfestő, bocskorkészítő, varga, csizmadia, kalapos) - kiegészítőkből álló hagyományos viselet még fennmaradt, de kezdték kiszorítani a gyári anyagok, amelyek eleinte még nem változtattak a korábbi szabásokon, de egyfajta utóvirágzását eredményezték a paraszti ruházatnak, jó példa erre a zselickisfaludi családi együttes (11., 12. és 13. ábra). Egy ifjúsági pályázatból magáról a házivászon készítéséről és a belőle készített háztartási textilekről és ruhadarabokról van egy vázlatos kadarkúti összefoglaló, melyből épp azt nem tudjuk meg, hogy miből ismerhették meg a kadarkútiakat ruházatuk alapján. $\mathrm{A}$ házi vászonszövés fennmaradt az 1950-es évekig is szinte minden parasztcsaládnál. A vászon felsőruházat addig fokozatosan kikopott a használatból, de a nőké még mindig bő- és sokszoknyás-blúzos-kendős maradt, a férfiak előbb elhagyták a vászon felsőgatyát, legfeljebb aratásban vették fel, vagy szétszabatták alsónadrágnak, helyette csizmanadrág majd pantalló lett általános. A pályázó adatközlője 1890-ben született, tehát 1920 körül, mint fiatalasszony pontosan látta miféle vászonöl- tözet volt divatban ${ }^{34}$. A kérdőíves válasz nem írja, hogy takácsok is laktak Kadarkúton, ezek a helyi iparosoknak, értelmiségieknek és a környékbelieknek dolgoztak, legfeljebb nagyon erős és vastag vásznat rendeltek meg nála a parasztasszonyok ${ }^{35}$. Felsőruhának nem a merev kenderfonalat, hanem az olcsó és puha gyári pamutfonalat alkalmazták az asszonyok. A lányok 12 évesen tanultak meg fonni, 14-15 évesen már szőni is. A vászon ruhákat lényegében nem szabták, mert négyszegletesre szőtt darabokból állították össze. A községben már a 20-as években voltak varrógépek is, de egyesek még kézzel varrtak. Mintás főszödéses darabok inkább ágynemük, háztartási textilek voltak (abrosz, törölközőkendő, vékaruha, vánkosvég, stb.), hímzést testi ruhákon alkalmaztak, pl. férfi ingeken. A női felsőruházat kor szerint változott, 40 év felett már egyre sötétebb színü lett és egyszínű. A református konty - mint a 10. ábráról írtam, fehér alapszínü csipkefordros, kerek volt, a katolikus fekete kendőböl kötött. Nagyon kedvelték a kékfestő által készített szoknyát és kötényt, a felsőszoknya alá 5-6 péntölt is vettek (7-8 szelesek voltak, 1 szél 50-70 $\mathrm{cm}$ is lehetett). A menyasszonynak fehér keményített anyagból varrónő készítette a szoknyát és a belebujós, előlgombos, hosszúujjú fehér blúzt, fehér kötényt, alulra fehér sifonból fodros keményített péntölöket. Hozománynak legalább 12 abrosznak, 12 törölközőnek, 2 párnának (vászon dunnahuzat, vagy egy dunna két huzattal) és 5 vánkoshuzatnak stb. kellett lennie még az 1950-es években is. A női gyászruha is tiszta fehér volt, mint más református falvakban a környéken. 1950 után még szőttek egy ideig, de már csak szőnyegeket. Ing-gatya együttesét „pár ruhá”-nak nevezték, mert általában együtt készült. A vőlegénynek 15 „pár ruhá”-val kellett, hogy készüljön a menyasszonya, aki barátnői segítségével varrta, hímezte az esküvő előtt. Ki tudja meddig volt ez követendő modell, de az 1920-as években még biztos. A férfiing dereka három vászonszélből, hosszú ujja egy-egy szélből állítódott össze, a gatyája 3-3 szélből (itt talán nem volt divat a nagyon bő). Az ünnepi ing zsebébe sifonból csipkés széllel díszített és hímzett nagyobb zsebkendő került, a jegykendő hasonló volt csak még díszesebb és nagyobb. Az iparosok városiasabb öltözéke hatott a kadarkútiakra. Az első vi-

34 A régi a 10-es számú fényképen lévő fiatalasszony a jellegzetes szennai és környéki református nöi viseletfélében van. Pontos részletek - különösen a kontynál - nem egészen állapíthatók meg. Fején mintha a régebbi „gódakonty” lenne, alul kendő hátrakötve, a fejbúbon csipkés, fodros, művirágos konty kiegészítő. Egyebekben a ruházata az 1920-as években is általános ünnepi ruházat, a kontyon lévő templomi csipke „férevető” (sálalakú kendő) nélkül. Bokrosinget, vállkendőt visel, utóbbit elől keresztbe téve és hátul megkötve derékon. Szoknyája lábszárközépig ér és bö, elöl csak a test elejét fedő, derékben kissé ráncolt félkötény van. A katolikusoknál a nők fejfedője sötét vagy fekete selyemböl hátrakötött és pillangósan álló kendő, alatta kis horgolt vagy horgolt szélü hajkontysapka, az idősebbeké gyapjúból. Teljes öltözéket nem láttam, idős asszony és férfi köznapi ruhája egy Gönyey Ébner konyhafelvételen van. Knézy 2001.240-246.

35 Molnár László: A házivászon alkalmazása és jelentősége Kadarkúton. Pályázat 1964-65 Rippl-Rónai Múzeum Néprajzi Adattára A testi ruházatban 1920 körül az ünnepi ruhát nem, köznapi felsőruhát esetleg készítettek pamutvászonból, megfestették kékfestöre. Alsó ruhának még megfelelt a pamutvászon, és nagyon sokféle konyhai, szobai textil, ágynemü, ponyva stb szövődött házilag. 


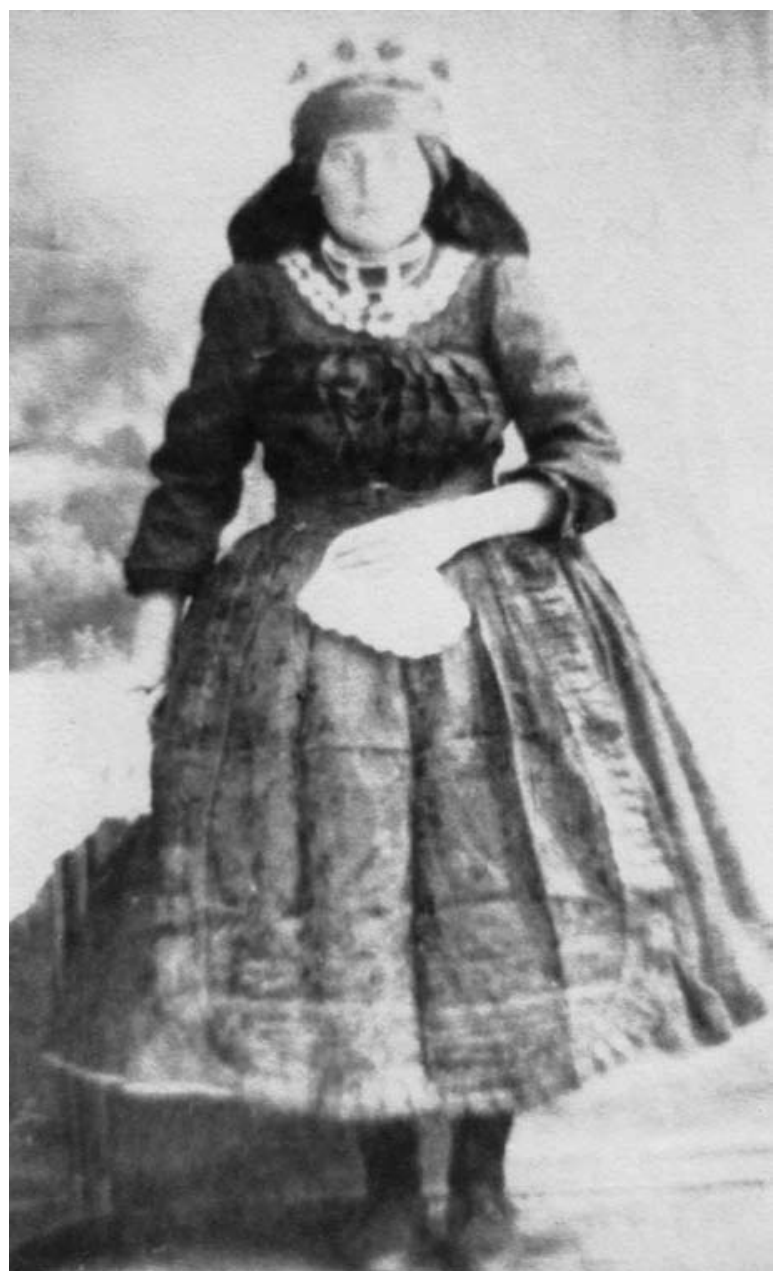

11. ábra. Fiatalasszony, Istvándi Jánosné, sz.

Bereknyei Katalin 1925-ben szennai ünnepi ún. "góda kontyos" viseletben, mely hátrakötött kendőböl és fejbúbra rögzített csipkefodros, virágdíszes fejkötőből állt hátul lelógó színes kontyszalagokkal. Szerzője ismeretlen.

Repro Gőzsy Gáborné. RRM NF-N-2706

lágháborút megjárt fiatal férfiak már nem szívesen vették fel az ünnepi fehér gatyát ezen a területen. Az iparos asszonyok sokkal hosszabb és sötétebb szoknyát hordtak, mint a parasztasszonyok, de nem tudni, hogy egyberuhát mikortól.

A kérdőív szerint a szokások közül az aratóünnepet és szüretet gyakorolják és fontosnak tartanák a régi táncok felújítását. Szerdánként van heti vásár, a válaszadó szerint a helyi kisipari temékeknek nincs jelentősége.

A község népe úgy tartja, hogy abban múlja felül a környező falvakat, hogy itt a vidék kereskedelmi központja és egészségügyi szempontból is a legjobban ellátott. A csatolt statisztikai táblázatok elárulnak számos sajátságot a község gazdálkodásáról, és külön érdemük, hogy a nagybirtokosok illetve középbirtokosok, kisgazdák gazdálkodásának számszerű adatait egyes témáknál külön is tárgyalják.

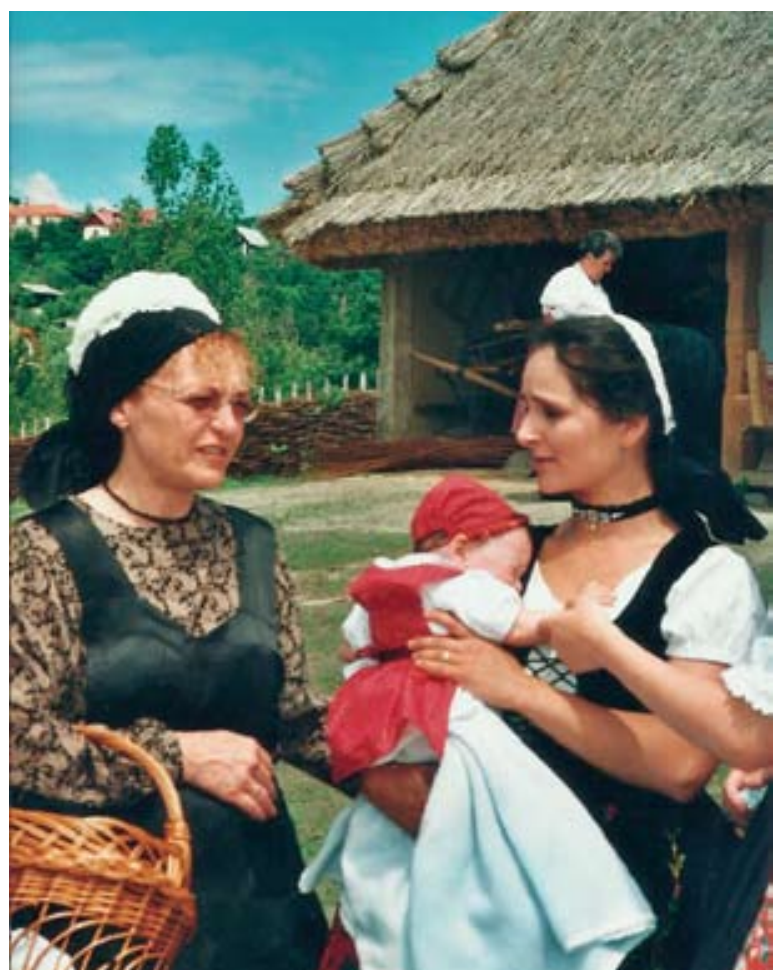

12. ábra. Rekonstrukciós bemutató Szentendrén a zselici tájegység megnyitója, az oda érkezett zselickisfaludi két fiatalasszonnyal az egykori kimenős parádésabb viseletben. A konty a 20-as évek elötti régebbi típus, melyet éppen azidőben váltottak fel hátrakötő kendő nélküli, de még fodrosabb fejkötöre. Szennán, Patcán, Kisfaludon és Szilvásszentmártonban stb. (A katolikus nők hajkontyán kis fejkötö volt, felül, hátrafogott, pillangósan megkötött, kikeményített kendő volt, a ruhájuk kissé színesebb) Knézy Judit felvétele és tulaajdona.

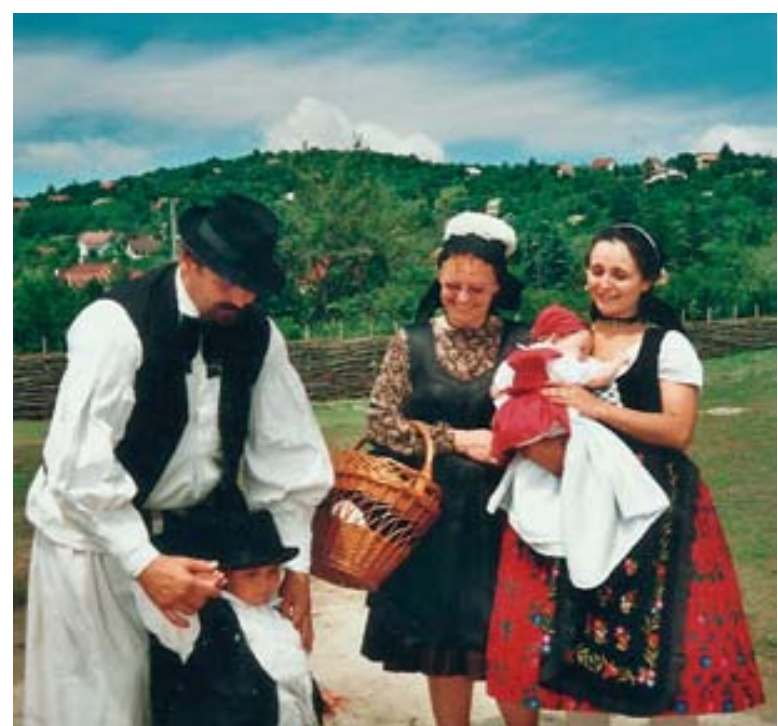

13. ábra. Szentendrén a somogyi porták bemutatóján zselickisfaludi fiatal család rekonstrukciós viseletben nagyobbrészt eredeti darabokból összeállítva. Knézy Judit felvétele és tulajdona 
1910-ben mezőgazdasági művelt terület: szántó 4261, kert 55, rét 601, szőlő 104, legelő 805 k.hold, nádas - erdő 202

Kisbirtokosoké: szántó 2150 , kert 13, rét 198, legelő 5198, erdő 49, terméketlen 247, összesen 3282 k.hold.

Községi közbirtokosságnak nincs kitöltve az adata.

Középbirtokosoké: összesen 828 k.hold, Márffy Emilé 553, Birth Oszkáré 827, gróf Széchenyi Miklósé 834 k.hold (részletezésétől eltekintettem).

Keresők száma: összesen 589 fő, ebből 100 hold felett 7 fö, 10-100 hold közötti gazda 77, 10 hold alatt 105, részes, kertész, mezőgazdasági cseléd 243, ipar, bánya, kereskedelem, közlekedés 157 fő. Lélekszám növekedés 40 év alatt $12 \%$.

Lakóházak száma 1910-ben 381 ebböl munkásház 26. Építésmódra és uradalmi épületekre nincs adat.

Állatállomány: 1911-ben 1918-ban ebből uradalmi 1920-ban

$\begin{array}{lrrc}\text { sertés } & 2928 & 2349 & 1915 \\ \text { juh } & 244 & 160 & 622 \\ \text { sz.marha n. } & 368 & 506 & 397 \\ \text { tehén, ökör } & 716 & 517 & \begin{array}{l}377 \text { növ, } \\ 408 \text { tehén, } \\ \end{array} \\ & & & \begin{array}{l}175 \text { ökör } \\ 445\end{array}\end{array}$

Igáserő száma, gazdasági gépek, gazdasági rendszer rovatok nincsenek kitöltve.

1913-ban 7 méhész, 40 kaptár, 30 kas, 3 rossz.

Termelvények és termésátlagok: búza $721 \mathrm{~h}$ (átlagtermés $7,71 q)$, rozs $620 \mathrm{~h}(6,25 q)$, árpa $171 \mathrm{~h}(5,02 q)$, zab $420 \mathrm{~h}(5,00 \mathrm{q})$, tengeri $587 \mathrm{~h}(7,94 \mathrm{q})$ burgonya $271 \mathrm{~h}$ $(39,71 q)$, cukorrépa $25 \mathrm{~h}(90,82 q)$, dohány $2 \mathrm{~h}(3,93 q)$, kender $2 \mathrm{~h}(3,95 q)$, bab $1 \mathrm{~h}(5 \mathrm{q})$, takarmányrépa $35 \mathrm{~h}$ $(142 q)$, bükköny 355h (15,19q), lóhere 259h (17,71q), lucerna $6 \mathrm{~h}(21,43 q)$, ugar $92 \mathrm{~h}$, réti széna $601 \mathrm{~h}(17,11 \mathrm{q})$, gyümölcs, zöldség.

Fanemek, népjellemzés rovatok kitöltetlenek.

\section{A kérdőíves válaszokban foglaltak Bárdudvarnokról}

E község jelenleg 16 településcsoportból áll, egykori önálló községekből (Bárd, Lipótfa, Bánya és Kaposszentbenedek) és pusztákból ${ }^{36}$. Bárdudvarnok statisztikai lapja hiányzik az ismertetett forrásból, tehát 1921 és 1926 évekből. Más adatok szerint: 1914ben lakói 1615 fö, ebből r.kat. 1110, ref. 505, házak száma 1110. 1932-ben lakói 1790 fö, 1950-ben 2330 fő, 1990-ben 1616 fő, ebből r.kat. 830, ref. 421 fö ${ }^{37}$. Kaposszentbenedek 1950 óta tartozik e községhez, előtte önálló volt. Helynevei mutatják egykori önállóságát: „Szentbéki” temető, református iskola, református templom, katolikus templom, községháza, Szentbéki Határárok ${ }^{38}$ és Malomdűlő.

36 F. Szabó 1932 adatai alapján Eperjessy idézi 2006 26, hogy az összevont községekhez hozzá tartoztak még: Bárdibükk, Péterkő, Olajhegy I-II., Felső-, Alsó- és Újzsippó, Középgyóta, Kopaszhegy, Vóta-, Magányos- és Szendipuszta, Öregzsippó.

37 Csánki 1912. 43.p. A többi év adatai: F. Szabó 1932. és a továbbiak Eperjessy Ernő 2006. 26. Kaposszentbenedeket kivéve a többi helységben együttesen több a katolikus

38 Végh 1974.166. sz. község 517-522.p. Több gyűjtő anyagát revi-
A jelenlegi község gyönyörü környezetével, változatos vidékével valóságos üdülőfalu, patakjával, tavaival, erdeivel, művésztelepével. Bárdudvarnok a Kaposmente nyugati szakasza és a Zselic ÉNY-i része közötti átmeneten található. A néprajzosok, földrajzosok a Zselic falvai közé sorolták. Tudomásom szerint a község történetéről Forintos László által írott munka még nem jelent meg.

A kérdőíves válasz szerint 1921-ben nem müködik itt sem szövetkezet, sem egylet, sem dalárda. Tervezik olvasókör alakítását. Azt állítják, hogy az előbbiekre eddig nem volt igény. Két iskola, egy állami, egy református müködik, utóbbi két tantermes. Ismétlőiskolásokról nincs adat. Ismeretterjesztő előadásokat nem tartanak. Kisdedóvó sincs. Népkönyvtárat még csak szeretnének, az iskolában kezelnék. Olvasókör létrehozásán gondolkodnak.

A Havasi vajvállalatnak van két fióktelepe a tej begyűjtésére. Működik egy gőzmalom, más ipari létesítmény nem. Elegendő közkút müködik, vízszintjük 10 méter mélyen van, de ártézi kút nincs. Okleveles bába dolgozik itt helyben, de orvos és gyógyszertár csak 12 km-re található. A közutak és szekérutak állapotát megfelelőnek találják, a járdák nincsenek semmivel lefedve. Nincs villany, így az utcák sincsenek kivilágítva. Sem vízművet nem akarnak, sem a villany szolgáltatást nem tudják megoldani. Tüzoltó készültség van két tűzoltófecskendővel. Háziiparról nem tud a jegyző - se kosárfonás, se hímzés, se szövés, se faragás - mondván, hogy hozzávaló nyersanyag sincs.

Amerikából a háború óta nem jött haza senki. Lakáshiány van. Egy kétszoba-konyha-mellékhelyiséges ház ára 1500 korona. Öt házhelyet osztottak újabban ki és nem hiányzik az építkezési terv se, van megfelelő agyag a tömésfalú házak készítéséhez, de tégla is ${ }^{39}$.

A községhez tartozó mezőgazdasági terület 5044 kat. hold, a kisgazdáké csak 1890, az árterület 10 hold, egyéb 90 hold. Földeladásnál magyar holdban számolnak (1200öl), de hivatalos adatokat kataszteri holdban adnak meg, például a kérdőív esetében is. Idegen határban csak Kaposszentbenedeken birtokolnak 20 kat. holdat. Nyomásgazdálkodást nem alkalmaznak, hanem „szabad gazdálkodást” üznek „3 forgósat” (őszi: búza, rozs; tavaszi: kapás, és a harmadik a takarmány). Fekete ugar nincs. „A határ nagyon széttagolt, ezért alkalmazzák a szabad gazdálkodást." A legjobb föld a vörösagyag a bárdi határban, a leggyengébb homokos - Szendi gödörben és Bányán. Természeti katasztrófákat szenvedtek el 1921-ben jégverést és szárazságot, 1912-ben peronoszpóra vészt, de 1922 sem számított könnyű évnek. Trágyázást 3-4 évenként végeznek, de műtrágyát nem használnak. Mezőgazdasági gépek közül a vető, kapáló, kaszáló és töltögető

deálta, összefoglalta dr Király Lajos 517-522. p.

39 Gönyey Ébner Sándor zselici tanulmányaiban Bárdudvarnokról is írt.1931 89-110. 1933.153-156. a faépítkezés emlékeiröl és a zselici kanászéletröl. A népi műemléki felmérések alapján a faépítkezés hagyományai a falvak belterületén hamarabb megszüntek, mint Szennán és környékén, de a szölöhegyek még sokáig örízték és őrzik az egykori borona és favázas pincék maradványait, és berendezéseit. (14. ábra) 


\section{HÁROM KÖZSÉG A ZSELIC NYUGATI SZÉLÉN 1921-27 KÖZÖTT KADARKÚT, BÁRDUDVARNOK, HEDREHELY NÉPÉNEK ÉLETKÖRÜLMÉNYEI}

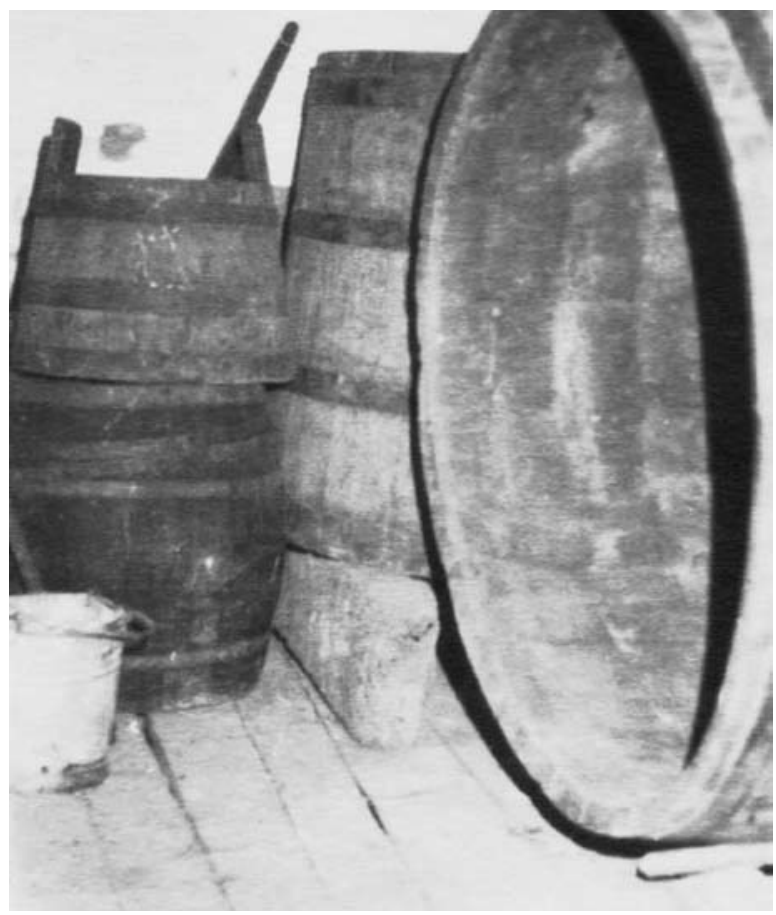

14. ábra. Bárdudvarnoki présházas pince belseje. Molnár Ágnes felvétele 1982-böl. RRM NF-N-2129

ekét használják. Hibának vélik, hogy a gépekre kevés súlyt helyeznek a gazdálkodásban. Rétjük elegendő, de a közlegelő nincsen kúttal és fasorral ellátva, nem elegendő és rosszul kezelik. A gazdálkodás fő ága az állatnevelés. A tejet Kaposvárra és a helyi tejcsarnokba hordják. Méhészettel a nagybirtokosok, és a vasutasok foglalkoznak, többnyire kaptárokat alkalmaznak. A korai cseresznyét nagy mértékben termelik és eladnak belöle. Egyébként a gyümölcsöt nyersen fogyasztják, feldolgozásnak nincs nagy hagyománya. Zöldségtermelésük jelentéktelen. 1913 óta 18 kat. hold szőlőt telepítettek, borukat kereskedők vásárolják fel. Hetivásár tartási joguk nincs. Földmunkásfeleslegről nem lehet beszélni, nem szegődnek távolabbi birtokokra. Kisiparosok szerepe nem jelentékeny. Természeti értékeikről mit sem tud írni a jegyző. Úgy tartják szerinte a kisgazdák, hogy a fejlődést a földhiány akadályozza.

1926. évi válaszuk szerint hét év alatt semmi sem szerveződött (egylet, szövetkezet, stb.). Viszont 10 házhelyet osztottak ki 1920-25 között Bárd ás Bánya területén. Nyolc ház fel is épült, de középületnek alkalmas szabad épülettel nem rendelkezik a falu. Úgy vélik, hogy helységük semmiben sem múlja felül a környező községeket. Nincsenek természeti értékek, romok, barlang, emlékfa, nem tartanak számon híres, itt született embert. Viszont a hősi halottak emlékét ápolják, 62-en haltak meg a háborúban, emléktáblát már állítottak, de szobrot is terveznek. Nyaraltatásra nincsenek meg a kellő feltételek, fő oka, hogy lakáshiány van és nem is lenne megfelelő tiszta alkalmas ház egész nyáron át. A község földesurai közül gróf Somssich Géza iskolaépületet adott, Petracsek Béla iskolatelket, dr. Gosztonyi
Mihály iskolakertet és a vasútállomás telkét. Ezért úgy tartják, hogy a legtöbbet a községért Gosztonyi Mihály és Petracsek Béla tett.

A Faluszövetségnek nem alakult itt fiókja. Oka a szegénység, nem tudják fizetni a tagdíjat. A Nép és a Vasárnapi Újságot járatják, de könyvet nem vásárolnak. A népkönyvtárat a kultuszminisztérium ajándékozta 1921 után az iskolának. Ismeretterjesztő előadásról nem tudnak beszámolni, de műkedvelő előadás kettő is volt az iskola 100 fös termében.

Nincs néprajzi gyűjtemény. Mesékről, mondákról nem tud a kitöltő. Feljegyzések sem találhatók a községről, krónikaíráshoz sincs senkinek kedve. Úgy vélik, jó példaadás kelthetné fel a lakosság érdeklődését, adakozó kedvét. Jellegzetes szokásokat sem sorol fel a jegyzö ${ }^{40}$. A régi táncok közül él még a csárdás. Új táncokat városi vendéglősök tanítanak. Rádió nincs a helységben. Testnevelötelep 1600 négyszögöles, de rosszul felszerelt. A levente mozgalom kezd népszerüvé válni, müvelődési céljai miatt is.

A közlekedés javítására jó utak építését szeretnék föképp a vasútállomásig. Buszjáratról nemigen esett szó.

A községi pótadó $50 \%$-os, amelyet igazságtalannak találnak, megszűntetnék. A kataszteri jövedelem megállapításánál aránytalanságok vannak, különösen a szőlöbirtokok tekintetében. A tanya létére természetesen nemleges a válasz és arra is, hogy távoli földjeiken kint alusznak-e. A kisbirtokosok földje 2-3 helyen van és nem akarnának tagosítást. A földbirtokreform során gróf Somssich Géza 72 k.holdat, Eszterházy Aladár 103 és 84 k.holdat adott, Gosztonyi Mihály 26 k.holdat. Az igénylők mind birtokba vették, de elégedetlenek a minőségével, nem tudják rajta a legszükségesebb terményeket megtermelni. Gigéből kaptak 84, Szennából 103 holdat. A terület átcsatolását kérnék, mert idegen községben aránytalanul több az adó. Az uradalmaktól nem bérelnek földet a kisgazdák.

Belátják, hogy igényesebb talajművelés által jobban haladtak elöre. Gazdálkodásukban továbbra is az állatnevelés és gabonatermelés, de a gyümölcstermesztés is fontos. A kisgazdák átlagtermése: búza holdanként $14 q$, rozs $10 q$, tengeri $10 q$, burgonya 40 mázsa. A kisgazdák $1 \%$-a adósodott el, nincs folyamatban per, végrehajtás. A földhiány miatt kevés a földeladás, leginkább magyar embereknek adnak el. Az uradalmi földek értéke azonos a kisgazdákéval. Üres beltelek négyszögöle 1914-ben 1 korona, 1926-ban 0.86 korona, kisgazda telke 1914-ben 1200 korona, 1926-ban 1500 korona. A legjobban gazdálkodó 2-3 kisgazda közül említendők: Jakab József 30 , István János 28, Balog Jánosné 14 holdas gazdák. Az aratók 10-ed részt kapnak, a cséplők 20\%-ot. A kisgazdák földjeinek ára:

40 Gönyey Ébner Sándor fent jelzett cikkeihez Bárdudvarnokon fényképezett itt: 1931-ben hasovány kerítést EF 65047, füstös házat kívülröl EF 65042, 65044, 65046, füstöskonyhát EF 65049-51, sertésólat EF 65047, 1932-ben Bognár István hosszifuruglás kanászt. Kaposszetnbenedekröl való a főzés a kemence tetején hátrakötött kendőkontyban EF 64 944, 64 9545, és 64948 It.számú tojásfestés. Molnár Ágnes 1982-ben gyűjtött Bárdudvarnokon, fényképsorozat készült: (RRM F 14167-70, pince tüzelöberendezése RRM F14155, konyha berendezésröl (kredenc, takaréktüzhelyröl, stb pl RRM F dig.14164-65 stb sertésvágásról is. 


$\begin{array}{llllll}\text { Szántó } & 1914 & 1926 & \text { rét } & 1914 & 1926 \\ \text { jó minőségű } & 800 & 800 & & 800 & 1100 \\ \text { közepes } & 700 & 700 & & 700 & 900 \\ \text { rossz } & 600 & 600 & & 600 & 800\end{array}$

$A z$ uradalmi földeket is tekintve legjobb minőségűek a Günnő, Diás, Zsippó, Szent Tamás, Kishegy, Csomakő dülökben vannak. Közepes minőségüek a Gazdi és a Szendi hegy, gyenge a Peterke. A kisgazdák távolabbi földjei $20 \mathrm{~km}$-re fekszenek. A távoli földek értéke $20 \%$-al ér kevesebbet, mint a közeliek. 1 hold föld átlagos haszonbére 1914-ben 20 korona, 1926-ban 28 korona, a napszámbér 40000 korona. A gazdasági cselédek bére a vármegyei rendeletnek felel meg.

Végső megállapítás, hogy a fejlődést a széttagoltság gátolja, sajnálják, hogy nem kellőképp használják a gépeket, de észrevették, hogy az igényesebb talajműveléssel előre haladtak.

\section{Hedrehely adatai a kérdőíves válaszokban}

Lakossága 1932-ben 1271 fő, magyar (rk. 543, ref. 713, izr. 15). Területe: 4512 kh. Hozzátartozik: Bende-, Sarolta-, Böczörpuszta, Bozdás major, Laposcser-, Alsókurja- Felsőkurja-puszta. Földbirtokos gróf Festetich Kálmán örökösei 813 kh, Márffy Elemér 312 kh. Bérlő Schmiedt Jenő 657 kh.

Hedrehely református hagyományai sok tekintetben meghatározták e közösség müködését már a 18. században is. Nemcsak a nagyszerü templom építéséböl világlik ez ki. Csokonai Vitéz Mihály is tanúja volt ottani tartózkodása idején, miként harcoltak a hedrehelyiek azért, hogy kedvelt lelkészüket ne helyezzék vissza Csökölybe, bár a csökölyiek nyertek ${ }^{41}$, de azt is megjegyezte, hogy mennyivel jobb a hedrehelyiek kenyere (búzából), mint a csökölyiek „lenpogácsája” és finomabb a boruk is. Gönczi Ferenc is kiemelte, hogy az 1920-as években gyüjtéseihez milyen sok segítséget kapott a református lelkésztől. A tanárok néprajzi érdeklődése további hagyomány: 1954-ben tartalmas, részletes hedrehelyi néprajzi-történeti monográfiát írt az iskola tanári kara. Márton István igazgató később helynévgyűjtésben is remekelt, s az arra „tévedő” néprajzosok patronálója volt. E pályázat kiadására sajnos nem került sor ${ }^{42}$.

A református összetartozást jelzi a kérdőíves válasz is az ünnepeken szereplő református dalárdáról és a tanító aktivitásáról. E községben református dalárda müködik 26 taggal, akik ünnepnapokon és állami ünnepeken szerepelnek, más nincs. Györkös Ferenc körjegyző, Németh József ${ }^{43}$ református lelkész és Kutas Ferenc tanító szervezi a lakosságot. Egy pusztai és egy református iskola működik, az ismétlőiskolások 18 fővel vesznek részt az oktatásban, melyben gazdasági ismeretek is szerepelnek. Az iskolában könyvtár is van. Kisdedóvó nem alakult. Ismeretterjesztő előadásokat a tanító tart,

41 Knézy 1996. 23-25

42 Hedrehely monográfiája 1954 RRM NA 93.

43 Gönczi 1937. 9. Könyve elöszavában többek között neki is megköszöni és a kadarkúti tanítónak is a terepmunkája alkalmával nyújtott segítségüket. utoljára 1921 októberében 20 hallgatója volt. Népakadémiát jónak tartanának, de valószínü nincs megfelelő helyük, mert azt mondják, hogy előbb népházat kellene építeni.

Hitel- és Fogyasztási Szövetkezet müködik a községben, másra nem gondolnak. Két gőzmalom található, de szesz-, konzerv-, téglagyár nem, még gabonaraktár sem. Közkutak vannak, de ártézi kút hiányában „fúrott” kutakból vesznek vizet, melyek kb. 30m mélyek, vízszintjük $26 \mathrm{~m}$ körül van. De változtatásra nincs konkrét terv, bár jónak tartanák. Okleveles bába lakik a községben, de orvos, gyógyszertár csak 6 km-re van.

A közutak állapota a lehető legrosszabb, okát a terepadottságokban és a kedvezőtlen tulajdonviszonyokban látják. Az utak egy része ösvényen vezet keresztül. Nincs villanyvilágítás, megfelelő áramfejlesztő (pl. vízierő) sem áll rendelkezésre. A járdákat semmi se fedi. Még szervezett tűzoltóság sincs, csak „köteles készültség" és egyetlen fecskendő. A háziipari ágak meglétéröl vázlatosak a megjegyzések: kosárfonást és a parasztasszonyok szövését méltatja a jegyző, megjegyezve, hogy csak saját céljukra szőnek ${ }^{44}$.

Amerikából a háború után nem jött haza senki (nem tudni meg ebből, hogy egyáltalán korábban ment-e ki valaki). Viszont lakáshiány van. Megfelelő lakásnak kétszoba-konyha mellékhelyiségből álló építményt

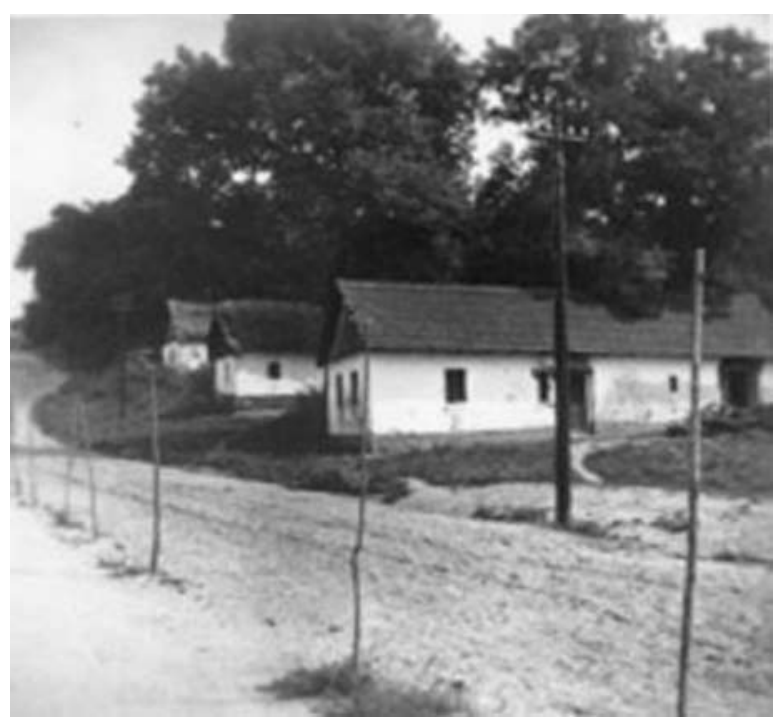

15. ábra. Pásztorházak Hedrehelyen párhuzamosan egymás mellett Takáts Gyula, a készítő szerint a „régi falurészben" 1951-ben. RRM NF-51.08.2.

Szinte egyforma három épület

tartanak, melynek ekkor 60-180 ezer korona az ára. Ebben az időben épülhettek a község aránylag régi részén a községi pásztorok házai, három is egymás mellett párhuzamosan (15. ábra).

44 Asszonyai szintén megszövik saját használatra a szükséges vásznakat, díszeseket is, viseletük hasonló a Szennai és környékiekéhez 1921 körül, szőni ők is kb 1950-es évekig szőttek. 


\section{HÁROM KÖZSÉG A ZSELIC NYUGATI SZÉLÉN 1921-27 KÖZÖTT KADARKÚT, BÁRDUDVARNOK, HEDREHELY NÉPÉNEK ÉLETKÖRÜLMÉNYEI}

A községben a mezőgazdasági terület 4366 kat. hold, melyből a kisgazdák 2662 holdon gazdálkodnak. Idegen község határában - Visnyén - van még saját földjük (eladásnál magyar holdban számolnak 1200 n.öl, de a kérdőívben katasztrális holdat adtak meg). Nyomás gazdálkodást folytatnak az 1894. évi t.cikk szerint, háromforgós művelésben (kapásnövény, tavaszi kalászos és őszi gabona), és nincs szabad gazdálkodás, se fekete ugar. Gépek előfordulnak a kisgazdák használatában (cséplő-, vető-, kaszálógép, nem tudni milyen arányban). Saját gazdálkodásuknak úgy tartják, nincs „feltűnő hibája”. Viszont a közlegelő nem elegendő és a legrosszabb minőségű, a javítás „nem kivitelezhető", de fásított egy része és van kút.

A gazdálkodásban az állatnevelést tartják a legfontosabbnak, a felesleges tejet nem tudják hova vinni. Van méhészet a kisgazdák körében kaptáros és kasos. A gyümölcstermést házilag feldolgozzák (egyes fajtákat lekvárnak, pálinkának, mást aszalványnak). A zöldségtermés sem megy piacra. Szőlőt nem telepítettek 1913 óta, borukat maguk fogyasztják el. (Megjegyzendő, hogy szőlőjük a Visnyei hegyen van - erről nem ír a válaszadó). Földmunkásfelesleg nincs és nem is szegődnek el messzebbi munkára a lakosok. Gazdálkodásukat hátráltatja a megfelelő közlegelő hiánya és a rossz útviszonyok.

1926-ban a második kérdőív már arról számol be, hogy a 31 háborús hősi halottnak szobrot állítottak. Újabb szövetkezetet nem alakítottak. Házhelyet nem osztottak ki. Közintézménynek nem áll rendelkezésre megfelelő épület. Önértékelésük szerint a környező falvakhoz képest jobb földjeik, szebb állataik vannak. $A z$ idegenforgalom fellendítéséhez szükséges látnivalók, kiadandó lakások, stb., nem állnak rendelkezésre. Van egy kolostorrom, de még saját levelezőlapjuk sincs, megfelelő vendéglőjük se.

A község népét - bevallás szerint - a földesurak semmiben se segítik, de a helyi elöljárók igen. Dr. Balla Pál körorvos, Bódis Géza tanító a kultúrával és testneveléssel, egyebekben pedig Mérey Lajos és Németh József aktívan működnek. A kérdőív alapos kitöltéséből látszik, hogy lelkiismeretes, hozzáértő vezetők állnak e faluközösség élén. Németh József lelkész Gönczi Ferencnek is sokat segített a Somogyi gyermek címü könyvéhez a gyüjtésben. De nincs néprajzi gyűjtemény, a községről fényképet sem készítettek, a faluszövetségnek nem alakult fiókja, nincs népkönyvtár, nem írnak és nem is szándékoznak községi krónikát írni, nincs mozielőadás, könyveket nem vesznek a kisgazdák - mindez „a falu közönye miatt” - írja a jegyző, valamint, hogy „a falu érdeklődése a közügyek iránt nem kelthető fel". Műkedvelő előadást nem tartottak, pedig az iskola egyetlen tantermében 80 fő is elfér. Viszont lapokat járatnak, mint a Pesti Hírlap és Magyarság (valószínű csak az értelmiségiek, s talán az iparosok). Iparosokról, háziiparról továbbra is kevés a közlés. Fazekasokat említi, hogy híresek a megyében. Valóban nem vittek árut a megyén túl, hanem nagyjából a Zselic északi és nyugati felében, Belső-Somogy déli felében kb. Nagyatád vonaláig és le a Dráváig. Minden- féle cserépárut készítettek, edényt, kályhát, még padlásszellőzőt is. Turbéki Istvánnak az 1920-as években remekműve az az archaikus formájú, az úri konyhák rézsütőinek mintájára formázott kuglófsütője, melynek az alja is gerezdes (16. ábra). Éppen abban az időben kezdték az asszonyok inkább keresni az olyan sütőt, melynek az alja egyenes és csak az oldala gerezdes. De a háromlábú nyeles „lábulábas” már abban az időben ritkábban készült, kiszorították a vasedények, de még pincékbe vittek ki ilyet (17. ábra ${ }^{45}$

Rádió van a helységben, a vendéglős Schisinger Jenő lehetővé tenné, hogy nála hallgassák a vendégek, de még a kisgazdák sehol sem hallgatják. Egy holdas testnevelötelepet elkülönítettek, de nincs fel-

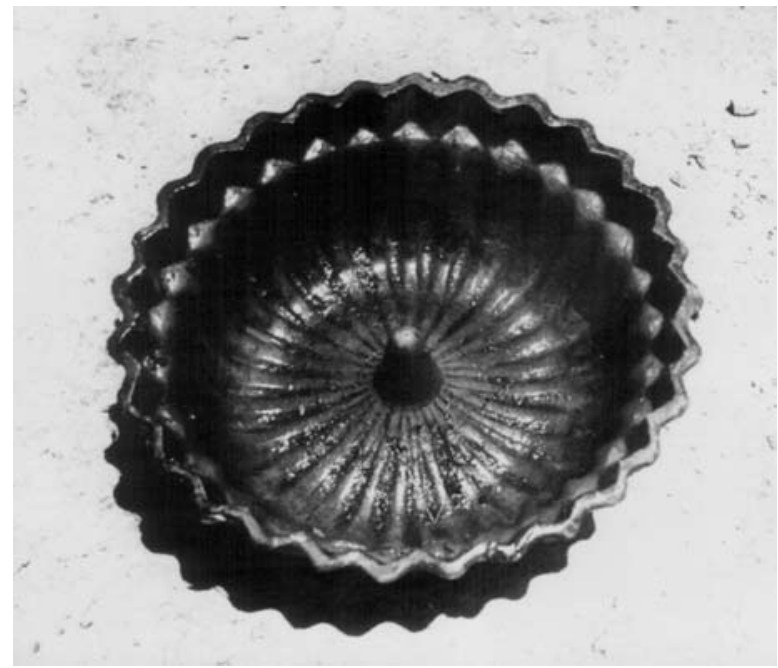

16. ábra. Cserép kuglófsütő kb 1920 körül,

Turbéki István készítette Hedrehelyen, zsuppos háza padlásán volt 1966-ben Knézy Judit felvétele. RRM NF-5379

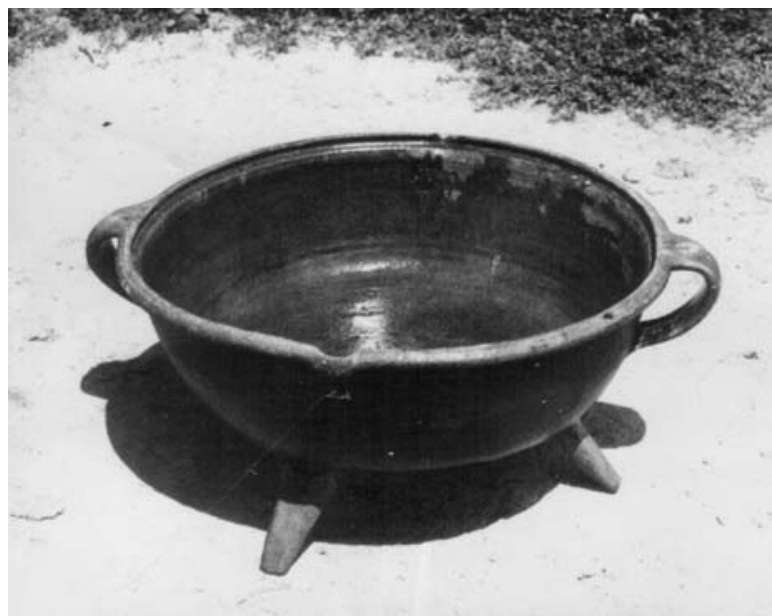

17. ábra. Cserép, nyeles háromlábú lábas „lábulábas” kb 1920 körül. Készítette Turbéki István, Knézy Judit felvétele. RRM NF-5390

45 Egyeztettek a barcsi, nagyatádi, szigetvári agyagiparosokkal hogy kinek meddig tart a körzete, melyet tele szekérrel felkeresnek, de vásárokon, piacokon együtt árulnak. Knézy 1974. 259282. 
szerelve, valószínű azért, mert a leventemozgalom nem népszerü.

Számos gondot megoldott volna a közlekedés rendezése. Hencsén 1924-25-ben lett vasútállomás 3,63 km-re, de elég rossz az odavezető út, esőben járhatatlan. Buszjáratról szó se volt addig. A községi pótadó $50 \%$-os, megszüntetését kívánatosnak tartanák. Községi jövedelem ingatlanokból nincsen. A tanyarendszer meglétét itt is hiába kérdezik. A kisgazdák birtoka 5-6 dülőben szerteszét volt eredetileg kiosztva és az adásvételekkel még bonyolódott a rendszer, de tagosítást nem akarnak.

Birtokreform eredményeképpen Festetics Kálmán gróf 1262 kataszteri holdat bocsájtott rendelkezésre a község délnyugati határrészéröl. Ebből 250 holdat vettek a lakosok birtokukba. A földéhség ezzel nem szünt meg a pénzhiány miatt. Az uradalomtól mégse bérelnek földet, de gépesítéssel sikerült elöre haladniuk a kisgazdáknak. Fő jövedelmük állattenyésztésből és gabonatermesztésböl adódik. A kisgazdák átlagtermése búza $10 q$ holdanként, rozs $7 q$, tengeri $28 q$, burgonya 36q, zab $7 q$, utóbbi a legjövedelmezőbb terményük. Az uradalom terméseredményei ugyanilyenek. De az uradalmi földek ára $10 \%$-al magasabb. A határban nincs terméketlen terület. A kisgazdák $50 \%$-a van eladósodva, de árverés nem gyakori. Földet helybeli és hencsei magyar, föként református lakosoknak adnak el. A kisgazda háza és telke 1914-ben 15000 korona, 1926-ban 110000 korona. Mezőgazdasági szakismeretek terjesztésével senki se foglalkozik. A legjobban gazdálkodók Kozma János 37 kat. holdas, Váradi Sándor 37 kat. holdas gazdák. $A z$ aratók 1/10-ed részt kapnak, a cséplörész 5-7\%.

Egy kataszteri hold jó minőségű szántóföld ára 1914ben 700 korona, 1926-ban 900-1000 korona,

\begin{tabular}{|c|c|c|}
\hline közepes minőségű & 500 & $800-1000$ \\
\hline $\begin{array}{l}\text { gyenge } \\
\text { Egy kataszteri hold }\end{array}$ & 400 & $650-800$ \\
\hline jó minőségű rét ára & 1100 & $1200-1300$ \\
\hline közepes minőségű & 950 & $1050-1200$ \\
\hline gyenge & 850 & $950-1050$ \\
\hline
\end{tabular}

A kérdőíves válasz részletezi, hol vannak - az uradalmakat is beszámítva - a legjobb, közepes és gyenge minőségű földek. A távol lévő földek ára 15\%-al kevesebb. A községtöl távol nem laknak kint kisgazdák, az út oda-vissza $2 \mathrm{~km}$. Egy hold haszonbére 1910-ben 10 aranykorona, 1926-ban 100 kg búza gazdák esetében, uradalmi földeknél 1914-ben 8 aranykorona, 1926-ban $60 \mathrm{~kg}$ búza és az adó. A munkásviszonyokat jónak tartják. A napszám télen 12000 , nyáron 35000 korona. A cseléd bére: $8 q$ búza, $8 q$ rozs, egy hold föld használata, fél öl fa, 1-2 állat tartása, 36000 korona évi készpénz. A 22 dülönévröl külön jegyzék van és nem hiányzik a statisztika sem. Lélekszám 1191, ebből magyar 1188 , német 3 fő. Vallás szerint 254 katolikus, 807 református és 20 izraelita. A kereső lakosság száma: 100 hold felett 2 fö, 10-100 hold között 72 fő, 10 hold alatt 103, mezőgazdasági cseléd 135, ipar, kereskedő 6 fö.
A földterület megoszlása: szántó 3280 kh, kert 115 kh, rét $318 \mathrm{kh}$, szőlő $3 \mathrm{kh}$, legelő $363 \mathrm{kh}$, nádas és erdő 363 kh, terméketlen 176 kh, összesen 4512 kataszteri hold. Ebből a kisgazdáké szántó 1883, legelő 82, rét 263, szőlő 3, erdő 46 kataszteri hold. A községé 27 hold szántó, 38 hold legelö, 1 hold rét, 129 hold erdő, összesen 292 hold. Középbirtok 1 fö: 310 hold szántó, 2 hold legelö, 1 hold erdő. Fischl Kálmán nagybirtokos szántója 950, kertje 7, rétje 54, legelője 158, erdeje 166 kataszteri hold. Neki még Visnyén és Németladon is van birtoka.

A lakóházak száma 1910-ben 260, ebből munkásház 24. Építési módokról, uradalmi épületekről a rovat kihúzva.

Az állatállomány

1911-ben: sertés 1812, juh -, sz,marha növ. 282, ökör 420, ló 503

1918-ban: sertés 1082, juh 344, sz.marha 301 , ökör 312, ló 451

1920-ban: sertés 1264, juh 246. n.marha 207 ökör 267, ló 431.

Méhész 8 fő 1913-ban, kasos tartás. A gazdasági gépek számát nem töltötték ki.

Termények: búza 1036h (átlagtermés $7,71 q$ ), rozs $407 \mathrm{~h}(6,29 q)$, árpa $142 \mathrm{~h}(5,02 q)$, zab $307 \mathrm{~h}(5,00 q)$, tengeri $427 \mathrm{~h}(7,94 q)$, burgonya $148 \mathrm{~h}(39,71 q)$, cukorrépa-, dohány-, kender $6 \mathrm{~h}(3,63 q)$, bab-, takarmányrépa $30 \mathrm{~h}(2,80 q)$, bükköny $260 \mathrm{~h}(15,19 q$,) lóhere $300 \mathrm{~h}$ $(17,71 q)$, lucerna $25 \mathrm{~h}(21,43 q)$, ugar $71 \mathrm{~h}$, réti széna 318h (14,19q), szőlő 3h, gyümölcs, zöldség kihúzva.

Végezetül nem szándékozom külön összefoglalót, összegzést írni, mert ebben az esetben az volt a legfontosabb, ami ezekben a dokumentumokban van leírva, nem annyira azok a gondolatok, amelyeket bennem keltettek. Próbáltam ugyan együtt gondolkozni a kérdőív összeállítójával és a választ adókkal, sok gondolatom is támadt, még több kérdésem. A véleményemet, kiegészítéseimet a bevezetőkben, a jegyzetekben, öszszekötő magyarázatokban, részben képekkel igyekeztem megtenni elsősorban néprajzi szempontból.

Minden tiszteletem, nagyrabecsülésem Dr. Bodor Antalnak e kérdőíves forrásanyag összeállítójának, összegyűjttetőjének, a pótlások kidolgozójának és megőrzőjének, de közvetlen segítőinek is. Csak remélni tudom, hogy mások is kíváncsiak lesznek erre a forrásanyagra és a korszakra - nálam avatottabbak -, amelyben ez a fontos dokumentáció megszületett. (Ma is gond, de másként a kis lélekszámú, elnéptelenedés felé tartó, vagy nagyon is küszködő falvak helyzete). Külön tiszteletet érzek a sok-sok egykori falusi jegyző iránt, akik sokat törhették a fejüket a válaszokon. Róluk tudunk a legkevesebbet, egyszer talán majd ír valaki róluk is könyvet. 


\section{HÁROM KÖZSÉG A ZSELIC NYUGATI SZÉLÉN 1921-27 KÖZÖTT KADARKÚT, BÁRDUDVARNOK, HEDREHELY NÉPÉNEK ÉLETKÖRÜLMÉNYEI}

\section{Irodalom}

BAKSAY S. 1896: Somogy megye. - In: Az Osztrák-Magyar Monarchia írásban és képben. IV. Budapest, pp. 263-360.

Borsos B. 2011: A magyar népi kultúra régiói. Dunántúl, Kisalföld, Alföld. - Mérték Kiadó, Budapest.

BoszNAI V. 1858: Zselicről. - Vasárnapi Újság, október 17. p. 501.

CsÁNKı D. (szerk.) 1912: Somogy vármegye monográfiája. Budapest

CsoRBA J. 1857: Szakácsi. Somogy vármegye ismertetése. - Pest, Emich Gusztáv nyomdája, p. 251.

ENDREI Á. 1912: Somogy vármegye népe. - In: Csánki D. (szerk.): Somogy vármegye monográfiája. Budapest, pp.197-222.

EPERJESSYE. 2006: Puszták népe a Zselicben (1900-1950). - Mikszáth Kiadó, Horpács, pp. 3-698.

FILEP I. 1858: Zselickisfalud. - In: Vasárnapi Újság, április 20. p. 22.

F. SzABó G. (szerk.) 1933: Somogy vármegye és Kaposvár megyei város általános ismertetője és címtára, az 1932 és 1933. évre. - Budapest

GÁBos D. 1926. Csököly község monográfiája. - Budapest

GAZDA I. 1984: In memoriam Bodor Antal. - In: Magyarország honismereti irodalma. Budapest

GöNCZI F. 1937: Somogyi gyermek. - Csurgói könyvtár VI., Kaposvár

GÖNYEY ÉBNER S. 1931: Adatok a Zselicség tárgyi néprajzához különös tekintettel a faépítkezésre. - Ethnographia XLII. 89 110.

GÖNYEY ÉBNER S. 1933: Zselici kanászélet. - Ethnographia XLIV. 153156.

GYÁNI G. 2000: A szociálpolitika első lépései hazánkban. Darányi törvényei. - In: Fehér Gy. (szerk.): Darányi Ignác emlékülés. Kiadja a Magyar Mezőgazdasági Múzeum Budapest, pp. 94110.

HoFER T. 1955: Dél-Dunántúl településformáinak történetéhez. Ethnographia LXVI.:125-186.

HoFER T. 1972: A magyar kettős udvarok kérdéséhez. - Ethnographia LXXXIII.: 20-42.

JaNKó J. 1897: Az Ezredéves Országos Kiállítás Néprajzi Faluja. 7. Ház. - Budapest, pp. 11-22.

KANYAR J. 1971: A gazdaságtörténeti kutatások jelentősége és szükségessége a Zselicben. - Pécs, Zselici Dolgozatok I.: 311.

KAPITÁNY O. és IMRŐ J. (szerk.:) 2001: Somogy Megye Népmüvészete. - Népmüvészeti Örökségünk sorozat, Kaposvár

Katona E. 2001: Posztóból készült viseletdarabok. - In: Kapitány O. Imrő J. (szerk.:) Somogy megye népművészete. Népművészeti Örökségünk sorozat, Kaposvár, pp. 173-194.

Kıss E. 1935: Alsó-Dunántúl mezőgazdasága II. - Kaposvár

KNÉZY J. 1966: A hedrehelyi gölöncsérek. - In: Takáts Gy. (szerk.): A Somogyi Múzeumok Füzetei 7. Kaposvár, p. 56

KNÉZY J. 1974: A Bencsik fazekascsalád története. - In: Mándoki L. (szerk.): Janus Pannonius Múzeum Évkönyve 14-15.: 259-282.

KNÉZY J. 1977: Csököly népének gazdálkodása és táplálkozása (18-20 század). - In: Kanyar J. (szerk): Somogyi Almanach 27.: 3-92.

KNÉZY J. 1980 : Faanyagok és fából készült használati tárgyak a zselici falvak paraszti háztartásában. - In: Zselici Dolgozatok V.: 36-39.

KNÉZY J. 1984-1985. A somogyi parasztság gazdálkodásának és táji csoportjainak változásai (1850-1914). - In: Für L. (szerk.): Magyar Mezőgazdasági Múzeum Közleményei 1984-1985. 381-407.
KNÉZY J. 1996: Csokonai és a csökölyiek határpere. - Hévíz 3. sz. 23-25 (Knézy Edit néven tévedésböl)

KNÉZY J. 2001: Táj, népcsoportok története, művészeti hatások. In: Kapitány O. és Imrő J. (szerk.): Somogy megye népmüvészete. Népmüvészeti Örökségünk sorozat. pp. 7-32.

KNÉZY J. 2001: A paraszti viselet változásai a XVIII-XX. században. - In: Kapitány O. és Imrő J. (szerk.): Somogy megye népmüvészete. Népmüvészeti Örökségünk sorozat. pp. 207-248.

KNÉZY J. 2006: A parasztszoba éke: a szemeskályha Somogy megyében a XVIII-XIX. században. - In: Holló Sz. A. és Szulovszky J. (szerk.): Az agyagművesség évezredei a Kárpátmedencében. Budapest - Veszprém, pp. 141-154.

KNÉZY J. 2012: Piacozó falvak Kapos mente nyugati szakaszán (18901960) - In: A Néprajz és Múzeológia. Tanulmányok a múzeum tudományok köréböl a 60 éves Viga Gyula tiszteletére. Miskolc pp. 331- 348

Kogutowicz K. 1930-36: Dunántúl és Kisalföld írásban és képben. Atheneum Nyomda, Szeged, p. 352

KósA L. 1991: Paraszti polgárosulás és a népi kultúra táji megoszlása Magyarországon (1880-1920). - Néprajz egyetemi hallgatóknak 12. Dél-Dunántúl - Göcsejtől Sárközig. Budapest, pp. 248-265.

KovÁcs F. 2000: Darányi az agrártudományért és szakoktatásért. - In Fehér Gy.(szerk.): Darányi Ignác emlékkonferencia. Kiadta a Magyar Mezőgazdaság Múzeum Budapest, pp. 48-53.

L. IMRE M. 1975: Varga János faragópásztor. - Somogyi Múzeumok Közleményei 2.:137-146.

MALONYAI D. (szerk.) 1911:A magyar nép művészete. III. A balatonvidék magyar pásztornép művészete. - Budapest, pp. 3-304.

MALONYAI D. (szerk.) 1912: A magyar nép művészete. IV. A dunántúl magyar nép müvészete. - Budapest

MoLNÁR I. 1987: Bodor Antal (1785-1955). - In: Für L. és Pintér J. (szerk..): Magyar agrártörténeti életrajzok. A-H. I. kötet. Magyar Mezőgazdasági Múzeum, Budapest, pp. 139-142.

MOLNÁR L. 1975: Somogy megye mezőgazdasági szakoktatása 90 éves. - In: Molnár L. (szerk.): Kaposvári Mezőgazdasági Főiskola Tudományos Közlemények. Kaposvár, pp. 3-264.

NAGYVÁTHY J. 1795: Közönséges instructio... Kézirat SML 138.

NESZMÉLYI K. 2000: Darányi szerepe a mezőgazdasági szakmai törvényalkotásban. - In: Fehér Gy. (szerk.): Darányi Ignác emlékkonferencia. Kiadja a Mezőgazdasági Múzeum Budapest, pp. 77-93

PALÁDI KovÁcs A. 2011: Somogy, Somogyság, Somogyország. Zselic Zselicség. - In: Magyar Néprajz I. 1. Táj, nép, történelem. Budapest, pp. 543-555

S. KovÁcs I. 2001: Pásztorélet, Pásztorművészet. - In: Kapitány O. és Imrő Judit (szerk.): Somogy megye népművészete. Népmüvészeti Örökségünk sorozat. Kaposvár pp. 329-372.

SzILI F. 1987: Vásárok Somogy megyében (1700-1848). - Somogy Megye Múltjából 18.: 182-220.

TARJÁN G. 1991: Fáziskülönbségek a dél-dunántúli népi építkezés XVIII-XIX. századi történetében. - In: Cseri M. és L. Imre M. (szerk.): Dél-Dunántúl népi építészete. Pécs-Szentendre, pp. 90-112.

VÉGH J. (szerk.) 1974: Somogy megye földrajzi nevei. - Akadémiai Kiadó, Budapest

VIKÁR B. 1905: Somogy megye népköltése. - Budapest

ZentAl T. 2011: A Dél-Dunántúl hímes templomai, Szenna - Pro Pannónia Kiadói Alapítvány, Pécs, pp. 5-191. 
